\title{
Paraneoplastic endocrine syndromes
}

\author{
Georgios K Dimitriadis', Anna Angelousi², Martin O Weickert', Harpal S Randeva', \\ Gregory Kaltsas',2,3 and Ashley Grossman ${ }^{3}$
}

1The Arden NET CoE, Warwickshire Institute for the Study of Diabetes, Endocrinology and Metabolism (WISDEM), University Hospitals of Coventry and Warwickshire NHS Trust, Coventry, UK

2Division of Pathophysiology, National and Kapodistrian University of Athens Medical School, Athens, Greece

${ }^{3}$ Oxford Centre for Diabetes, Endocrinology and Metabolism, University of Oxford, Oxford, UK

Correspondence should be addressed to G K Dimitriadis

Email

g.dimitriadis@warwick.ac.uk

\begin{abstract}
The majority of neoplasms are responsible for symptoms caused by mass effects to surrounding tissues and/or through the development of metastases. However, occasionally neoplasms, with or without endocrine differentiation, acquire the ability to secrete a variety of bioactive substances or induce immune cross-reactivity with the normal tissues that can lead to the development of characteristic clinical syndromes. These syndromes are named endocrine paraneoplastic syndromes when the specific secretory components (hormones, peptides or cytokines) are unrelated to the anticipated tissue or organ of origin. Endocrine paraneoplastic syndromes can complicate the patient's clinical course, response to treatment, impact prognosis and even be confused as metastatic spread. These syndromes can precede, occur concomitantly or present at a later stage of tumour development, and along with the secreted substances constitute the biological 'fingerprint' of the tumour. Their detection can facilitate early diagnosis of the underlying neoplasia, monitor response to treatment and/or detect early recurrences following successful initial management. Although when associated with tumours of low malignant potential they usually do not affect long-term outcome, in cases of highly malignant tumours, endocrine paraneoplastic syndromes are usually associated with poorer survival outcomes. Recent medical advances have not only improved our understanding of paraneoplastic syndrome pathogenesis in general but also enhanced their diagnosis and treatment. Yet, given the rarity of endocrine paraneoplastic syndromes, there is a paucity of prospective clinical trials to guide management. The development of well-designed prospective multicentre trials remains a priority in the field in order to fully characterise these syndromes and provide evidence-based diagnostic and therapeutic protocols.
\end{abstract}
Key Words
- endocrine tumours
- paraneoplastic syndromes
- SIADH
- hypercalcaemia
- Cushing's syndrome
- acromegaly
- hypoglycaemia

Endocrine-Related Cancer (2017) 24, R173-R190

\section{Introduction}

The term paraneoplastic syndrome (PNS) was first described in the 1940s when it was recognised that certain neoplasms may cause various symptoms that are not solely attributable to direct tumour invasion, compression and/ or the development of metastases (Guichard et al. 1949). Such neoplasms present or acquire in time the ability to secrete a variety of biologically-active substances that can lead to the development of distinctive clinical syndromes. These syndromes are termed paraneoplastic because the secretory components responsible for their development are not derived from the anticipated organ or tissue of origin. PNS can be the product of tumour-secreted peptides, 
Table 1 Criteria for defining ectopic hormonal (paraneoplastic) syndromes.

Endocrine or metabolic disturbance in a patient with a tumour

Remission after successful treatment

Return of endocrine syndrome with tumour recurrence

Abnormally regulated elevated hormone levels

Significant gradient between hormone concentration in the venous effluent from the tumour and arterial hormone levels

Extracts from tumour exhibit bio- and/or immunoreactive hormone

Relevant hormone mRNA can be identified in tumour tissue

Synthesis and secretion of relevant hormone by tumour cells in vitro

amines or cytokines, or immune cross-reactivity between neoplastic and normal tissues, and can originate from either endocrine or non-endocrine neoplasms (Pelosof $\&$ Gerber 2010). The occurrence of PNS is influenced by the histology of the underlying neoplasm, and while such behaviour can often be explained in tumours of endocrine origin, it is not as yet fully understood in cases of nonendocrine neoplasms. The criteria for the diagnosis of endocrine PNS are shown in Table 1.

PNS can develop during different phases of the evolution of the neoplastic process, with an estimated prevalence of approximately 8\% among all malignant neoplasms (Baijens et al. 2006). In some cases, PNS can manifest itself before the diagnosis of the underlying malignancy and may facilitate diagnosis at an early and potentially reversible disease stage (Tarin 2013). Furthermore, the presence of PNS and measurement of the related aetiological factor can be used to monitor response to treatment and/or detect recurrence of the tumour following initial successful treatment. Effective and prompt diagnosis and treatment of the PNS may substantially improve overall clinical outcomes. However, occasionally, in the presence of highly aggressive tumours or extensive disease burden, management of these syndromes may be difficult and their presence can contribute to the morbidity and mortality of the underlying disease (Kaltsas et al. 2010). As currently available therapies for a number of neoplasms evolve and highly specific diagnostic modalities become widely used, patients with tumours will live longer, and thus the prevalence of PNS will likely also increase (Oberg et al. 2016). In the present review only endocrine PNS will be considered, excluding those related to different pathophysiological processes and/or exhibiting manifestations in other systems.

\section{Paraneoplastic endocrine syndromes}

Paraneoplastic endocrine syndromes mostly result from the production of bioactive substances from neoplastic cells, of endocrine or neuroendocrine origin, that are widely distributed throughout the lungs, gastrointestinal tract, pancreas, thyroid gland, adrenal medulla, skin, prostate and breasts (Agarwala 1996, Modlin 2008). A distinctive feature of endocrine PNS is that related symptoms cannot be attributed to the presence of a secreting neoplastic lesion related to the originating anatomic site, and thus the secretion of peptides, amines or other bioactive substances is regarded as ectopic (Kaltsas 2010). This is particularly relevant as neoplasms without endocrine differentiation may also acquire the ability to synthesise and secrete these bioactive substances, leading to clinically similar endocrine tumour-derived PNS (Table 2).

The clinical manifestations of these ectopic hormonal secretion syndromes may be clinically indistinguishable to those encountered when the neoplastic lesion is found in the expected site of origin (eutopic hormonal secretion), thus causing diagnostic dilemmas (Keffer 1996, Kaltsas et al. 2010). Neoplasms that cause endocrine PNS exhibit a wide range of malignant potential, ranging from being essentially of benign or low malignant potential to highly malignant tumours. However, the development of PNS does not always correlate with tumour stage, malignant potential and/or overall prognosis (Spinazze et al. 2006).

A number of histopathological classification systems of endocrine tumours originating from different endocrine tissues, such as gastrointestinal neuroendocrine tumours (GI-NETs), lung NETs, adrenomedullary and adrenocortical tumours, skin and thyroid tumours, have emerged providing information regarding the malignant potential of such tumours. In contrast, the great majority of endocrine PNS produced from non-endocrine neoplasms are found in highly malignant tumours mainly involving the lungs, breasts, prostate, ovaries, skin, colon and certain forms of haematological malignancies; however, tumours arising from virtually any tissue have been implicated, albeit rarely (Lorch et al. 2007, Nimalasena et al. 2008, Gilmore et al. 2009, Nella et al. 2014, Dimitriadis et al. 2015, Thajudeen et al. 2016).
C 2017 Society for Endocrinology Printed in Great Britain
Published by Bioscientifica Ltd 
Table 2 Ectopic Cushing's syndrome (CS): differences in clinical, laboratory and radiological features compared to eutopic secretion.

\begin{tabular}{|c|c|c|c|c|c|}
\hline Syndrome & Mediator & Tumour & Clinical/biochemical & Endocrine testing & Radiological \\
\hline \multirow{9}{*}{$\begin{array}{l}\text { Cushing's } \\
\text { syndrome (CS) }\end{array}$} & ACTH and & $\mathrm{SCLC}$ & Hypokalaemia/cachexia & $\uparrow A C T H$ (isoforms) & Pituitary MRI (-) \\
\hline & & Carcinoid tumour & Cushingoid phenotype & $\begin{array}{l}\text { HDDSST (-), CRH } \\
\text { (DDAVP test) }(-)\end{array}$ & BIPSS (-) \\
\hline & & Thymus, mediastinum & & & ${ }^{111}$ In Octreotide SRS (+) \\
\hline & & Thyroid (MTC) & & & 18F-FDG-PET (+) \\
\hline & & PICT & & & 18F-DOPA-PET (+) \\
\hline & & Pheochromocytoma & & & $\begin{array}{l}\text { 68Ga-PET DOTATATE } \\
(+)\end{array}$ \\
\hline & & $\mathrm{GI}$ & & & 123|-MIBG (+) \\
\hline & & Head & & & \\
\hline & & $\begin{array}{l}\text { Abdomen (paraganglioma, } \\
\text { ovary, other) }\end{array}$ & & & \\
\hline
\end{tabular}

${ }^{111}$ In SRS, ${ }^{111}$ Indium somatosatin receptor scintigraphy; ${ }^{18 F-D O P A-P E T, ~ f l u-d i h y d r o x y p h e n y l a l a n i n ~ p o s i t r o n ~ e m i s s i o n ~ t o m o g r a p h y ; ~}{ }^{18 F-F D G-P E T, ~}$ fludeoxyglucose positron emission tomography; ${ }^{68} \mathrm{Ga}$-PET DOTATATE, gallium positron emission tomography; ACTH, adrenocorticotropic hormone; BIPSS, bilateral inferior petrosal sinus sampling; $\mathrm{CRH}$, corticotrophin-releasing hormone; DDAVP, desmopressin; GI, gastrointestinal; SCLC, small cell lung cancer; HDDSST, high dose dexamethasone suppression test; MIBG, metaiodobenzylguanidine; MTC, myeloid thyroid cancer; PICT, pancreatic islet cell tumours.

Prompt endocrine PNS recognition may facilitate the diagnosis of an underlying unsuspected neoplasm, avoid extensive investigations to identify a presumptive eutopic hormonal-secreting neoplasm, and will allow for the monitoring of the clinical course and response to treatment of the underlying tumour (Pierce 1993, Bollanti 2001).

\section{Pathogenesis}

Although several attractive hypotheses have been proposed for the pathogenesis of endocrine PNS, the exact events that lead to their development are still elusive (Spinazze et al. 2006). It is well known that all human cells carry the same genetic information of which only part is expressed through their life span. However, under certain conditions specific alterations of gene function may activate genes that regulate hormonal synthesis, particularly in the context of an underlying neoplastic process, leading to the development of endocrine PNS (Granot \& Fridlender 2015). Inappropriate gene expression heralds the unscheduled appearance of a gene product at an unusual time of life or in an atypical cell, tissue or organ leading to a PNS, as encountered in many different animal species (Tarin 2013). However, the precise mechanism that initiates ectopic hormonal synthesis and release during the neoplastic transformation at a specific time point stills remains to be defined (Kaltsas et al. 2010).

Ectopically produced bioactive substances from endocrine and non-endocrine neoplasms leading to endocrine PNS are mostly peptides and hormones, and less commonly biogenic amines, steroids or thyroid hormones (Kaltsas et al. 2010, Dimitriadis et al. 2016). The symptoms are produced following the direct secretion of these substances from the tumour to the circulation, although they may also exert paracrine and autocrine effects. When symptoms develop, ectopically related hormones are found in large quantities in the serum. In a minority of patients, there may be different types of pancreatic NET hormone secretion which may also alter over time (Crona et al. 2016). Occasionally, the synthesis and/or processing of these compounds may be different from that of the eutopically secreted hormone leading to diagnostic uncertainty (Newell-Price 2003). In addition, as the secretion of these hormones is usually aberrantly regulated, the response to endocrine testing is different to that anticipated if eutopically secreted (Kaltsas et al. 2010).

\section{Diagnostic methods for detecting endocrine PNS}

Suspicion of an endocrine PNS can direct relevant diagnostic investigations accordingly. Non-endocrine tumours associated with endocrine PNS mainly involve the lung, breast, prostate, skin, colon and haematological malignancies. The majority of lung tumours are either small or large cell (SCLC or LCLC), or tumours of squamous origin (Nauck et al. 2007). Squamous cell tumours are usually large and can be detected using conventional cross-sectional imaging (computerised tomography, CT) with a sensitivity and specificity of 
89\% and 93\%, respectively, in one series (Toyoda et al. $2008)$; in cases of a suspected lesion without radiological confirmation, ${ }^{18}$ F-FDG-PET shows $79 \%$ sensitivity and 91\% specificity (Benjamin et al. 2003). Magnetic resonance imaging (MRI) is increasingly used in the diagnosis for both in situ and invasive forms of breast tumours (Behrendt et al. 2014) with $>90 \%$ sensitivity but only $72 \%$ specificity (Menezes et al. 2014). Multiparametric MRI is widely used for prostate cancer detection with $88 \%$ sensitivity and 74\% specificity, respectively (De Rooij et al. 2014). Most imaging modalities for malignant skin neoplasms exhibit low sensitivity and specificity, although molecular pathways/targets are currently being explored (Hong et al. 2008). Various imaging methods are employed for the diagnosis of colorectal tumours, yet the 'gold standard' remains optical colonoscopy (OC). Other modalities include CT colonoscopy with very high sensitivity (100\%), while MRI has 84\% sensitivity and 95\% specificity when evaluating lesions $>1 \mathrm{~cm}$ (Kekelidze et al. 2013). In the case of haematological malignancies, CT is the modality of choice (Shankland et al. 2012). PET scanning with ${ }^{18} \mathrm{~F}-\mathrm{FDG}-\mathrm{PET}$ CT is increasingly being used in the management of lymphomas with $80 \%$ sensitivity and 90\% specificity; however, PET scans are most widely used to assess responsiveness to therapy (Shankland et al. 2012).

Various radiological modalities are utilised for the diagnosis of endocrine tumours. Functional imaging aims at demonstrating the presence of somatostatin receptors (sstr) and uptake mechanisms on their surface (Kwekkeboom et al. 2009). The reported overall sensitivity of somatostatin receptor scintigraphy (SRS) for welldifferentiated (grade 1 and 2) GI-NETs is $>80 \%$. The sensitivity of SRS is lower in tumours with a diameter generally $<1 \mathrm{~cm}$, due to insufficient tumour-to-background uptake ratios of radioactivity, and is also low in NETs with a high Ki-67 index or neuroendocrine carcinomas (NECs), reflecting dedifferentiation and loss of sstr expression (Sundin et al. 2012). ${ }^{68} \mathrm{Ga}$-DOTATATE or ${ }^{68} \mathrm{Ga}$-DOTATOC is superior to SRS SPECT-CT showing higher sensitivities for lesion detection (>90\%), particularly due to better resolution or sstr affinities (Wild etal.2013). Radioiodinated MIBG, ${ }^{123}$ I-MIBG, is a guanethidine analogue that shares structural features with noreadrenaline and is used for imaging of phaeochromocytomas, paragangliomas and neuroblastomas (Jacobson et al. 2010). However, ${ }^{123}$ I-MIBG scintigraphy has lower sensitivity than SRS for GI-NETs $(50 \%)$ and pancreatic NETs (<10\%) (Kaltsas et al. 2001). Fluorine-18-L-3,4-dihydroxyphenylalanine (18F-DOPA) PET/CT showed the highest sensitivity (98\%) as compared with SRS and ${ }^{11} \mathrm{C}-5$-hydroxy-L-tryptophan (11C-5-HTP) PET for the detection of GI-NETs, but not pNETs (Van Essen et al. 2014). ${ }^{11} \mathrm{C}-5$-HTP is a radiolabelled precursor in the serotonin synthesis: ${ }^{11} \mathrm{C}-5$-HTP PET showed the highest sensitivity (96\%) for the detection of pNETs as compared with CT, SRS or ${ }^{18} \mathrm{~F}-\mathrm{DOPA}$ PET (Gotthardt et al. 2010). Cholecystokinin 2 (CCK2) receptor expression has been demonstrated in NETs with 111In-DOTACCK, ${ }^{99} \mathrm{mTc}$-demogastrin and ${ }^{111}$ In-DOTAMG11. ${ }^{68} \mathrm{Ga}$-DOTAminigastrin radiopharmaceuticals have shown $97 \%$ sensitivity for the detection of tumour deposits in patients with medullary thyroid carcinoma (MTC) (Froberg et al. 2009). Another radiopeptide used for targeting the GLP1R is (Lys(40)(Ahx-HYNIC-99mTc/EDDA) NH2)-exendin-4, GLP1R imaging using this compound has been studied in MTCs (Pach et al. 2013).

There is currently a paucity of reliable biomarkers to aid the diagnostic process in cases of non-endocrine neoplasia. This is partially due to the pathobiological diversity of non-endocrine neoplasia and its generally more aggressive biological behaviour (Oberg et al. 2016). In endocrine neoplasia, particularly in NETs, certain markers developed based on specific tumour-secreted compounds can improve chances of tumour detection (Oberg et al. 2016). Besides traditional biomarkers developed for the detection of endocrine malignancy, there is currently a considerable interest in areas such as blood transcript analysis, circulating tumour cells (NetTest) and miRNA measurement, although yet there are significant limitations before application into general clinical practice is likely (Modlin et al. 2016).

\section{Common endocrine PNS secondary to the secretion of peptide hormones}

\section{Hypercalcaemia}

The hypercalcaemia of malignancy is one of the most common endocrine PNS occurring in up to $10 \%$ of all patients with advanced tumours, and conveys a poor prognostic factor as the 30-day mortality can reach 50\% (Ralston et al. 1990, Lumachi et al. 2008). Paraneoplastic hypercalcaemia occurs in the absence of metastases or altered parathyroid gland function and can be caused by a variety of humoral substances that exert different effects on calcium homeostasis. Although ectopic parathyroid hormone $(\mathrm{PTH})$ or 1-25-dihydroxy $(\mathrm{OH})_{2}$ vitamin D3 secretion have been associated with the humoral hypercalcaemia of malignancy (HHM), in the majority of cases $(>80 \%)$ it results from the secretion of parathyroid

Published by Bioscientifica Ltd 
hormone-related protein (PTHrP) (Stewart 2005, Van den Eyden et al. 2007).

Parathyroid hormone is composed of 84 amino acids, whereas PTHrP comprises of 139-173 amino acids; although they exhibit different C-terminal portions they share the first $13 \mathrm{~N}$-terminal amino acids (Stewart 2005, Van den Eyden et al. 2007). PTHrP folds into a configuration that can bind to the PTH receptor, although it can also bind to other receptors, via which it exerts different effects from PTH (Van den Eyden et al. 2007). It has effects upon tissues other than bone, including the skin, anterior pituitary and mammary gland, and causes more widespread symptoms than elevated PTH although there is some overlap (Lumachi et al. 2008). It can be produced as four different alternatively-spliced messenger RNA transcripts, and at least two peptide isoforms are known to exist. Hypomethylation of the promoter has been implicated as a mechanism of its aberrant gene expression (Strewler 2000).

PTHrP-related hypercalcaemia occurs most commonly with squamous cell tumours and SCLC (Donovan et al. 2015), but it is also seen with endocrine tumours including GI-NETs (Stewart 2005, Van den Eynden et al. 2007). In two lung squamous cell carcinoma xenograft models of hypercalcaemia, the inhibition of autocrine epidermal growth factor receptor (EGFR) signalling has been shown to reduce plasma PTHrP and total calcium concentrations (Lorch et al. 2007). Amphiregulin stimulation of EGFR resulted in high levels of PTHrP gene expression in squamous cell carcinomas (Gilmore et al. 2009). Furthermore, the reconstitution of the amphiregulinEGFR signalling system in a squamous cell carcinoma line led to HHM and rapid osteolytic growth in animal models (Gilmore et al. 2009). This is a potential mechanism of non-endocrine neoplasia induced hypercalcaemia. Breast and testicular malignancies, and certain haematological malignancies including multiple myeloma, lymphomas and chronic lymphocytic leukaemia, can cause hypercalcaemia via this mechanism, at least in part (other mechanisms may also be involved) (Shionoiri et al. 2000, Stewart 2005, Kampfenkel et al. 2010). Other malignancies can also be associated with PTHrP-related hypercalcaemia. A recent review identified 29 cases of malignant colorectal tumours causing PTHrP-mediated hypercalcaemia. Most patients were middle-aged men with advanced metastatic cancer and severe hypercalcaemia (62\% with Ca $>14 \mathrm{mg} /$ $\mathrm{dL}, 3.5 \mathrm{mmol} / \mathrm{L}$ ) and were associated with high mortality and a short median survival (Galindo et al. 2016).

PTHrP-related hypercalcaemia is currently considered as the most common mechanism of endocrine tumour-related hypercalcaemia and can be encountered in GI-NETs, phaeochromocytomas and carcinoid tumours (Mantzoros et al. 1997, Abraham et al. 2002, Brzozowska et al. 2009, Kaltsas et al. 2010). Pancreatic NETs were initially considered to be a relatively common group of tumours associated with ectopic PTHrP secretion, but a recent single centre study identified this to be a relatively rare event (Kamp et al. 2014).

Rarely, hypercalcaemia may result from ectopic 1,25-dihydroxy $(\mathrm{OH})_{2}$ vitamin $\mathrm{D}$ secretion, particularly in association with certain haematological malignancies (lymphomas) and NETs, or from ectopic PTH secretion (Stewart 2005, Van den Eyden et al. 2007). Another mechanism of HHM may be mediated by granulocyte colony-stimulating factor (G-CSF), as a long-term exposure to G-CSF results in the stimulation of osteoclastic bone resorption and/or an increase in osteoclast progenitors (Hiraki et al. 2004). The over-secretion of macrophage inflammatory protein 1a (MIP-1a) has also been implicated in a myeloma case simultaneously secreting PTHrP and MIP-1 $\alpha$ (Shimizu et al. 2011). Cases of hypercalcaemia attributed to true ectopic PTH secretion are rare. In a recent literature review, 32 patients with tumours originating from the head and neck (7), thorax (8), GI-pelvis (11) and gynaecological (5) neoplasms, including a number of endocrine and NETs, were reported causing hypercalcaemia secondary to PTH secretion (Kandil et al. 2011).

Symptom severity depends not only on the degree of hypercalcaemia (calcium levels $>3 \mathrm{mmol} / \mathrm{L}$ ), but also on the rapidity of onset and the patient's baseline neurologic and renal function (Stewart 2005). The optimal approach to paraneoplastic hypercalcaemia is the treatment of the underlying tumour. In cases of intractable hypercalcaemia, treatment directed against the elevated calcium levels should be undertaken as per recent guidelines (including bisphophonates and possibly denosumab), while cinacalcet has been shown to be particularly efficacious in cases of PTHrP-related hypercalcaemia (Collins et al. 1998, Takeuchi et al. 2016).

\section{Syndrome of inappropriate anti-diuretic hormone secretion (SIADH)}

The syndrome of inappropriate anti-diuretic hormone secretion (SIADH) is characterised by hypo-osmotic, euvolemic hyponatraemia in the absence of plasma hypotonicity, and it occurs in $1-2 \%$ of all patients with malignant tumours (Castillo et al. 2012, Thajudeen et al. 2016). SIADH is most commonly found in SCLC

Published by Bioscientifica Ltd 
although it can also result from LCLC (Raftopoulos 2007, Castillo et al. 2012, Thajudeen et al. 2016). SIADH is also seen in $2-4 \%$ of non-SCLC patients, including those suffering from prostate, breast, adrenal cancer and lung carcinoids (Raftopoulos 2007, Castillo et al. 2012, Thajudeen et al. 2016). In SCLC, SIADH has been associated with a higher propensity for central nervous system metastases, poor response to chemotherapy and advanced stage of cancer (Thajudeen et al. 2016). There appears to be no clinical and/or biochemical features distinguishing the origin of the tumour although most severe symptoms are encountered in patients with highly aggressive tumours (Selmer et al. 2016); hyponatraemia grade at short-term follow-up was also predictive for long-term survival (Shepshelovich et al. 2015). In primary care patients, all levels of hyponatraemia are associated with increased all-cause mortality, whereas hyponatraemia per se is linked to an increased risk of being diagnosed with any malignancy, particularly pulmonary and head-and-neck malignancies (Selmer et al. 2016).

Inappropriate action of anti-diuretic hormone $(\mathrm{ADH}$, vasopressin), and nearby secreted oxytocin, have been identified in related neoplasms, being also implicated in tumour growth, exhibiting autocrine and paracrine signalling activities (De Lellis \& Xia 2003). The relation between SIADH and ectopic ADH production by tumour cells has also been demonstrated in in vitro studies as high concentration of immune-reactive $\mathrm{ADH}$ has been found in tumour extracts of patients with SIADH (Thajudeen et al. 2016). Northern blot and $S_{1}$-nuclease analysis demonstrated the production of ADH mRNA in tumours and tumour cell lines from patients with SCLC and hyponatraemia. Similarly, ADH has also been detected in SCLC tumours by radioimmunoassay and bioassay of anti-diuretic activity. Tissue cultures derived from ADHproducing SCLC demonstrated the presence of $\mathrm{ADH}$ in only a fraction of cells. Evidence for the production of $\mathrm{ADH}$ by only selected cells is also supported by the finding of persistent SIADH in patients who had a marked decrease in tumour size (Grohe et al. 2015).

The symptoms of SIADH depend on the degree and rapidity of hyponatraemia onset. Serum sodium levels $<125 \mathrm{mmol} / \mathrm{L}$, particularly if developing within $48 \mathrm{~h}$, manifest as altered mental status, seizures, coma, respiratory collapse and death (Ellison \& Berl 2007). When hyponatraemia develops during a longer time frame, neurologic complications may not occur (Raftopoulos et al. 2007). The optimal therapy for paraneoplastic SIADH is related to the treatment of the underlying tumour, which if successful normalises sodium level in weeks. It has been suggested that in patients with malignancy the use of an $\mathrm{ADH}$ receptor antagonist could improve hyponatraemic symptoms even in patients on palliative care. More studies are required to address the potential safety concerns of chronic use, because tolvaptan, a V2-receptor antagonist, is an excellent choice, especially in patients with lung malignancies (Grohe et al. 2015, Thajudeen et al. 2016). It has recently been shown that prompt endocrine input improved time for the correction of hyponatraemia and shortened length of hospitalisation, and the widespread provision of endocrine input should be considered (Verbalis et al. 2014, Grant et al. 2015, Tzoulis et al. 2016).

\section{Cushing's syndrome (CS)}

Approximately $10 \%$ of Cushing's syndrome (CS) cases are considered to be of paraneoplastic origin with approximately $50 \%$ being secondary to lung NETs (bronchial carcinoids, SCLC and rarely LCLC) (Barbosa et al. 2005, Teves et al. 2005, Morandi et al. 2006). Less commonly, paraneoplastic CS (PN-CS) may develop from neuroendocrine cells of the thymus, MTC, pancreas or chromaffin cell tumours (phaeochromocytomas, paragangliomas and neuroblastomas) (Ilias et al. 2005, Isidori et al. 2006). In a recent study performed by Kamp and coworkers looking at a large cohort of patients with thoracic and GEP-NETs, the reported prevalence of PN-CS was 3.2\% (Kamp et al. 2016).

It can also rarely arise from NE cells originating from the ovary or prostate (Nimalasena et al. 2008). Paraneoplastic CS occurs secondary to tumour secretion of adrenocorticotropic hormone (ACTH) or very rarely of corticotrophin-releasing hormone (CRH) (NewellPrice et al. 1998, Newell-Price et al. 2006). The ectopic ACTH syndrome is caused by abnormal expression of the POMC gene product arising from non-pituitary tumours in response to ectopic activation of the pituitary-specific promoter of this gene. Methylation of the CpG islands in the promoter region is associated with silencing of some genes. Using bisulphite sequencing and hypomethylation in five thymic carcinoid tumours resected from patients with ectopic ACTH syndrome, its presence correlated with POMC over-expression and the ectopic ACTH syndrome (Ye et al. 2005). Methylation near the response element for the tissue-specific POMC activator PTX1 diminishes POMC expression, implying that the methylation and expression patterns are likely to be set early or prior to 
neoplastic transformation and that targeted de novo methylation might be a potential therapeutic strategy (Newell-Price 2003).

Endocrine and neuroendocrine tumours producing PN-CS are in the majority of low malignant potential although this may change during the course of the disease (Ilias et al. 2005, Isidori et al. 2006, Li et al. 2016). Well differential lung NETs (typical and atypical carcinoids) account for the majority of PN-CS, approximately $36-46 \%$, producing a clinical and biochemical syndrome resembling pituitary dependent CS (Li et al. 2016, Zhang \& Zhao 2016). Symptoms and biochemical manifestations typically evolve gradually and usually do not produce a severe CS phenotype (Li et al. 2016). Although a variety of invasive and non-invasive endocrine and imaging studies may be utilised, a number of these tumours may still elude localisation or become apparent later during the course of the disease (Hofland \& Lamberts 2001). In such cases medical treatment of hypercortisolaemia and regular imaging studies to identify such lesions is usually advocated (Nieman et al. 2015). Paraneoplastic CS syndrome due to ACTH secretion from MTC appears to be relatively rare as it was only detected in 10/1640 patients with MTCs (0.6\%) (Barbosa et al. 2005). Phaeochromocytomas secreting ACTH are considered to be even rarer, accounting for approximately $5.2 \%$ of all cases of ectopic ACTH related CS (Ballav et al. 2012). Pancreatic NETs associated with PN-CS account for up to $10 \%$ of ectopic CS. In a recent study of 10 pNETs causing PN-CS, the mean age at diagnosis was 42 years, whereas the 5 and 10 year overall survival rate was 35\% and $16.2 \%$, respectively (Maragliano et al. 2015). Thymic NETs associated with PN-CS are also relatively rare and are usually associated with a worse outcome, but ectopic ACTH is a fairly common manifestation of thymic carcinoids and may occur in association with MEN-1 (Jia et al. 2017). In a study of 12 patients the median age at presentation was 21 years, median tumour diameter $5 \mathrm{~cm}$, while urinary free cortisol levels were found to be grossly elevated (Neary et al. 2012). Six recurrent patients developed metastatic disease and died 57 months following initial thymectomy (Neary et al. 2012). Figure 1 illustrates a thymic carcinoid tumour which secreted ACTH intermittently to cause periodic Cushing's syndrome (Trott et al. 2016).

Paraneoplastic CS from NETs has occasionally been attributed to CRH secretion such as carcinoids, MTCs and chromaffin cell tumours (Ilias et al. 2005, Isidori et al. 2006). In such cases, endocrine testing may be difficult to interpret as there is interplay between the findings

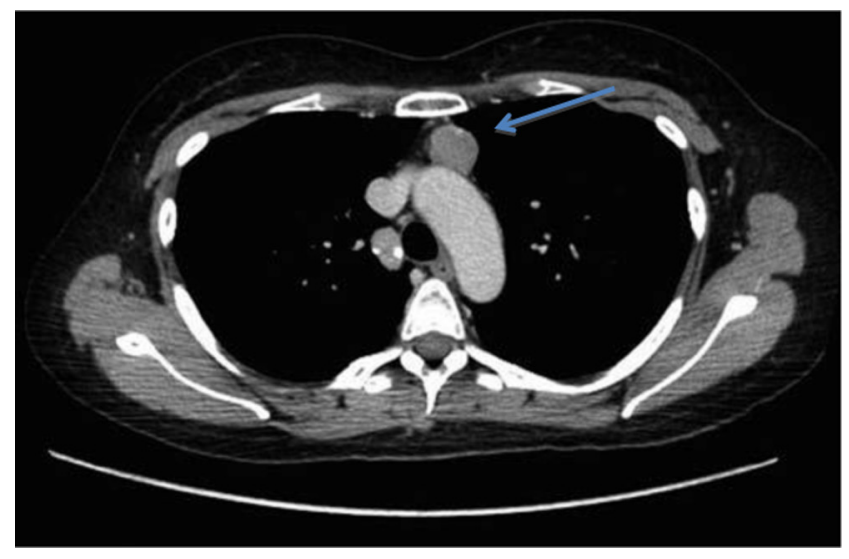

Figure 1

Thorax computerised tomography (CT) demonstrating a $24 \mathrm{~mm}$ anterior mediastinal thymic carcinoid. Reproduced under the terms of the original CC BY licence, from Trott et al. (2016).

of ectopic and eutopic production of these compounds, although usually there is a co-secretion of both ACTH and CRH (Howlett et al. 1986, Oldfield et al. 1991, Chrysoulidou et al. 2008).

Approximately $8-20 \%$ of PNS-CS is related to SCLC, although the secretory potential of ectopically produced ACTH of these tumours is much higher than that encountered in NETs (Ilias et al. 2005, Isidori et al. 2006, Kaltsas et al. 2010). In contrast to patients with PN-CS derived from NETs, patients with SCLC do not generally exhibit the classical symptoms of gradually evolving endogenous hypercortisolaemia with the exception of being exposed to high levels of cortisol (Bollanti et al. 2001, Ilias et al. 2005, Isidori et al. 2006). The symptoms/signs of the underlying malignancy along with weight loss, electrolyte and metabolic abnormalities are commonly encountered (Bollanti et al. 2001, Ilias et al. 2005, Isidori et al. 2006). The diagnosis is usually suspected on the basis of the rapidity of symptom development, relevant history of excessive smoking and radiological findings (Rueda-Camino et al. 2016). The severity of PN-CS can occasionally be so excessive that it may lead to cardiorespiratory failure (von Stempel et al. 2013). The impact of PN-CS in SCLC patients has been evaluated in a recent study (Nagy-Mignotte et al. 2014). Among 383 patients with SCLC, 23 had PN-CS, 56 other PNS (OtherPNS) and 304 had no PNS (NoPNS). After comparison of the three groups, PN-CS patients had more extensive disease, greater weight loss $(\geq 10 \%)$ and a reduced objective response to first-line treatment ( $47.6 \%$ vs $74.1 \%$ vs $71.1 \%)$ and poorer sensitivity to first-line treatment (19\% vs $38.9 \%$ vs $48.6 \%)$, respectively. On relapse, the PN-CS group had no objective response to second-line treatment vs $25 \%$

Published by Bioscientifica Ltd. 
and $42.8 \%$ in OtherPNS and NoPNS groups, respectively (Nagy-Mignotte et al. 2014). The median survival of PN-CS patients was 6.6 months vs 9.2 months for otherPNS and 13.1 months for noPNS patients. It was concluded that PN-CS is a prognostic factor of early demise (hazard ratio, 2.31) (Nagy-Mignotte et al. 2014).

Small cell carcinoma (SCC) of the prostate is an uncommon condition but there are a very few cases in which presenting symptoms are consistent with CS (Rueda-Camino et al. 2016). It may be suspected when laboratory features appear in patients diagnosed with prostatic adenocarcinoma with metastases that becomes resistant to specific therapy; prostatic-specific antigen levels are usually normal. The prognosis is very poor as 2and 5-year survival rates are 27.5 and $14.3 \%$, respectively (Rueda-Camino et al. 2016). Ectopic ACTH secretion associated with CS can also be rarely due to pancreatic acinar cell carcinoma (ACC) and pancreatoblastoma, rare tumour types with morphologic features sometimes overlapping those of pNETs (Maragliano et al. 2015).

Several studies have attempted to provide clinical, biochemical and radiological features aiming at distinguishing the origin of $\mathrm{PN}-\mathrm{CS}$ in respect to the malignant potential of the tumour (Table 3).
PN-CS treatment focuses on the management of the severe metabolic disruptions followed by rapid resolution of the hypercortisolaemia, and subsequent confirmation of the cause. Emergency lowering of the elevated serum cortisol when the syndrome is severe is most rapidly achieved with oral metyrapone and/or ketoconazole; if parenteral therapy is required then intravenous etomidate is rapidly effective in almost all cases (Preda et al. 2012), but all measures require careful supervision. If medical treatments fail, bilateral adrenalectomy should be performed in the shortest possible time span to prevent the debilitating complications of uncontrolled hypercortisolaemia (Nieman et al. 2015).

\section{PNS hypoglycaemia}

Tumour-associated or paraneoplastic hypoglycaemia occurs rarely and is caused by insulin-producing nonislet cell tumours and tumours secreting substances that can induce hypoglycaemia by non-insulin mediated mechanism (Iglesias \& Diez 2014). However, the majority of cases are the result of tumour-associated hypoglycaemia without excess insulin secretion secondary to the secretion of peptides capable of causing

Table 3 Endocrine and non-endocrine tumours causing paraneoplastic syndromes.

\begin{tabular}{l} 
Paraneoplastic syndrome \\
\hline Common \\
Humoral hypercalcemia of malignancy (HHM) \\
Syndrome of inappropriate anti-diuretic hormone secretion \\
(SIADH) \\
Cushing's syndrome \\
Less common \\
Non-islet cell tumour hypoglycaemia (NICTH) \\
Gynaecomastia/virilisation ( $\beta$-hCG) \\
Rare \\
Acromegaly \\
Hypertension \\
Ovarian hyperstimulation syndrome/PCOS like \\
Hyperprolactinaemia \\
Hyperthyroidism \\
Secretory diarrhoea \\
Tumour induced osteomalacia (TIO) \\
Ileus \\
Acute inflammatory reaction/pyrexia
\end{tabular}

\section{Tumour types}

Squamous cell (head and neck, lung, skin), breast, genitourinary (ovary, testis), lymphomas, renal, multiple myeloma, chronic lymphocytic leukaemia, lung (SCLC), colorectal, GI-NETs

Lung (squamous, SCLC, LCLC, bronchial carcinoids), prostate, breast, adrenal, GI

Lung (SCLC, bronchial carcinoids, LCLC), thymus, MTC, PNET, pheochromocytomas, pargangliomas, neuroblastomas

Mesenchymal tumours (sarcomas, GIST), renal, ovary, NETs Lung (SCLC, bronchial carcinoids), GCT (seminomas, teratomas, choriocarcinomas, yolk sac), pNETs

pNETs, lung (bronchial carcinoids), choristomas, hamartomas, gliomas, gangliocytomas Lung (SCLC, bronchial carcinoids), paragangliomas, renal, DSRCT pNETs, lung (bronchial carcinoids) Lung (SCLC), mesenchymal tumours Ectopic pituitary adenomas, struma ovarii Lung (SCLC), MTC, pheochromocytoma, renal Mesenchymal tumours, prostate, colon Glomus tumours (skull base) Pheochromocytomas, mesenchymal tumours, angiomatoid fibrous histiocytoma

$\beta$-hCG, beta-human chorionic gonadotrophin; DSRCT, desmoplastic round cell tumours; GI-NETs, gastrointestinal neuroendocrine tumours; GIST, gastrointestinal stromal tumours; LCLC, large cell lung carcinoma; MTC, myeloid thyroid carcinoma; PCOS, polycystic ovary syndrome; pNETs, pancreatic neuroendocrine tumours; SCLC, small cell lung carcinoma.

() 2017 Society for Endocrinology Printed in Great Britain
Published by Bioscientifica Ltd. 
glucose utilisation by different mechanisms such as insulin-like growth factor 2 (IGF2) precursors, IGF1 and glucagon-like peptide-1 (Kaltsas et al. 2010, Iglesias \& Diez 2014). Tumour autoimmune hypoglycaemia may also occur secondary to insulin receptor auto-antibody production, whereas excessive tumour burden with glucose consumption, massive tumour liver infiltration, and pituitary or adrenal gland destruction by the tumour are the other mechanisms in cases of large and aggressive neoplasias (Iglesias \& Diez 2014).

Non-islet cell tumour hypoglycaemia (NICTH) presents as recurrent or constant hypoglycaemic episodes and mostly affects elderly patients with advanced tumours (Teale \& Wark 2004, Dimitriadis et al. 2015). Occasionally, these hypoglycaemic episodes can predate the diagnosis of the underlying tumour (Nayar et al. 2006, Kim et al. 2016). The majority of cases of NICTH are usually caused by tumour cell production of IGF2 (Iglesias \& Diez 2014). NICTH is characterised by low serum insulin and C-peptide levels, low growth hormone (GH) and IGF1 levels, normal or elevated IGF2 levels and an elevated IGF2:IGF1 ratio (Teale \& Wark 2004, Nayar et al. 2006, Iglesias \& Diez 2014). In some cases of NICTH, expression of 'big' IGF2 has been reported and rarely there is expression of pro-IGF2 (Beckers et al. 2003, Hamberg et al. 2006). High concentrations of pre-pro-IGF2 levels that are not properly glycosylated result in the high molecular weight 'big' IGF2 that has a significantly higher affinity to the insulin receptor, and a lower affinity to its binding protein (IGFBP3), leading to increased bioavailability, enhanced peripheral glucose consumption and suppressed hepatic glucose production (de Groot et al. 2007, Rikhof et al. 2009). The majority of tumours associated with NICTH are mesenchymal and epithelial tumours although a number of NETs have also been described (de Groot et al. 2007, Kaltsas et al. 2010). In a recent review, 32 cases of IGF2 secreting tumours with hypoglycaemia that underwent radical surgery were identified; in 19 patients, hypoglycaemia was reversed and there was no subsequent recurrence. The remaining 13 patients experienced tumour recurrence or metastasis an average of 43 months after initial tumour resection (Otake et al. 2015). Although mTOR pathway blockade may represent a possible target regarding the management of malignant insulinoma-induced NICTH, an interesting case of an adrenocortical carcinoma secreting IGF2 not responding to everolimus was recently reported by Korevaar and coworkers (Korevaar et al. 2014). It appears that either IGF2 does not cause hypoglycaemia by activation of the insulin receptor, which is improbable, or that the mode of action of everolimus in this situation was not downstream of the insulin receptor. It is possible that the IGF1R and insulin receptor $\mathrm{A}$ or $\mathrm{B}$ may form receptor hybrids when co-expressed on the same cell (Korevaar et al. 2014).

A case of ectopic insulin secretion by a renal cell carcinoma with positive ${ }^{68} \mathrm{Ga}$-DOTANOC imaging and ex-vivo immunoreactivity for insulin has recently been reported (Ramkumar et al. 2014), along with an ovarian tumour of mixed neuroendocrine and yolk origin secreting insulin, leading to paraneoplastic hypoglycaemia (Battocchio et al. 2015).

\section{Acromegaly}

Acromegaly unrelated to a pituitary GH-secreting adenoma is very rare, accounting for less than $1 \%$ of cases (Melmed et al. 2006). Since the discovery of growth hormone-releasing hormone (GHRH) 30 years ago, it became apparent that the majority of these cases are GHRHrelated as this peptide can be synthesised and expressed in multiple extrapituitary tissues (Christofides et al. 1984, Melmed et al. 2006). In a recent review, only 74 published cases were identified and except for a recent French series of 21 cases most were case reports (Garby et al. 2012). Tumours secreting GHRH are mainly NETs, usually welldifferentiated and of pancreatic or bronchial origin accounting for approximately $2 / 3$ of cases (Fainstein et al. 2007, Butler et al. 2012, Lock et al. 2014). The clinical presentation is variable with features similar to those caused from a somatotroph adenoma. These tumours are usually large and easy to localise whereas the pituitary imaging may be normal or enlarged and difficult to interpret, especially in multiple endocrine neoplasia type-1 (MEN1) cases. Plasma GHRH measurement has an excellent specificity for the diagnosis, using a threshold of $250-300 \mathrm{ng} / \mathrm{L}$, and is a good tool for the follow-up of patients after treatment. These tumours have a good overall prognosis although approximately 50\% develop metastases (Borson-Chazot et al. 2012). Single cases of NETs causing acromegaly have been described from the duodenum (Colak Ozbey et al. 2009), liver (Furrer et al. 2001) and pancreatic tumours in the context of MEN1 (Biermasz et al. 2007, Weiss et al. 2011, Sala et al. 2013). Hypothalamic tumours, including hamartomas, choristomas, gliomas and gangliocytomas, may also produce excessive GHRH resulting in acromegaly (Di Lorgi et al. 2007). Ectopic secretion of GH has only been described in single cases (Melmed et al. 2006, Fainstein et al. 2007) and represents approximately $0.1 \%$

Published by Bioscientifica Ltd 
of paraneoplastic acromegaly cases (Melmed et al. 2006, Fainstein et al. 2007).

\section{Less common endocrine PNS secondary to the secretion of peptide hormones}

Ectopic renin secretion Cases of extra-renal reninproducing tumours are particularly rare, mostly related to NETs (paragangliomas and carcinoids) and SCLC leading to a hypertensive PNS (Dayal et al. 1986). Other extremely rare cases of renin-secreting tumours including desmoplastic round cell tumours (DSRCT) secreting ectopic renin (Lee et al. 2014). Cases of renin secretion from renal or pulmonary carcinomas have also been described (Ganguly et al. 1973). The renin-secreting tumour triad consists of hypertension, hypokalaemia and elevated plasma renin activity (PRA). Tumour resection is the therapeutic option of choice with various cases of chemo-sensitive tumours responding well to chemotherapeutic regimes. Adjuvant use of various antihypertensives, spironolactone or rarely aliskiren has proven to be helpful in offering temporary symptom relief (Rosei et al. 2015).

\section{Ectopic $\beta$-human chorionic gonadotrophin (bhCG} production) Gynaecomastia is a relatively rare PNS associated with tumour-secreted bhCG. There are several reports of paraneoplastic gynaecomastia secondary to thoracic (mainly SCLCs, carcinoids and extragonadal germ cell tumours) clinically associated with gynaecomastia in men, menstrual irregularity and virilisation in women, and precocious puberty in children (Braunstein et al. 1972, DeLellis \& Xia 2003, Yaturu et al. 2003, Mehta et al. 2008, Dimitriadis et al. 2017). Rarely, secretion of bhCG results from clear cell renal tumours (Mohammed et al. 2008) or liver carcinomas (Teniola \& Ogunleye 1994). A bhCG-like protein is also found in a variety of normal tissue, and there is evidence to suggest that the ahCG subunit may exert a paracrine effect on the growth of tumour cells (Rivera et al. 1989); bhCG may also act as a growth factor in SCLCs (Szturmowicz et al. 1995). Treatment is tumour resection or multi-agent chemotherapy in cases of chemosensitive malignancies such as SCLC.

Ectopic gonadotrophin production A handful of cases of ectopic gonadotrophin-secreting tumours leading to PNS are reported in the literature. In cases of the ectopic secretion of follicle stimulating hormone (FSH), patients may present with ovarian hyperstimulation syndrome
(Roberts et al. 2005, Burgos et al. 2009, Miras et al. 2015). Ectopic secretion of luteinising hormone (LH) has also been described presenting with phenotypic characteristics resembling the polycystic ovary syndrome (PCOS, Brignardello et al. 2004, Piaditis et al. 2005). Definitive treatment for these rare tumour cases remains the resection of the primary site.

Other ectopic pituitary hormonesecretion Ectopic secretion of prolactin secondary to a SCLC has been reported (Turkington 1971). Another case of hyperprolactinaemia secondary to a low-grade malignant mesenchymal tumour of the uterus with positive SRS has also been described (Simsir et al. 2012). Following successful removal of the mass, the hyperprolactinaemia which was previously refractory to dopamine agonist treatment was resolved, but immunohistochemistry for prolactin was negative (Simsir et al. 2012). Anecdotal cases of ectopic TSH secretion have been mentioned in the literature; ectopic TSH-secreting pituitary adenomas have occasionally been described (Bollanti et al. 2001, Pasquini et al. 2003).

Ectopic gut hormone secretion Paraneoplastic syndromes associated with ectopic secretion of gut peptides are very rare. Cases of vasoactive intestinal polypeptide (VIP) secretion causing typical watery diarrhoea has been described secondary to SCLC, MTC, phaeochromocytoma and NETs arising from the kidney (Said \& Faloona 1975, Tischler et al. 1984). Glucagonlike peptides (GLP) 1 and 2 are hormones derived from the post-translational processing of pro-glucagon in the intestinal $\mathrm{L}$ cells that influence intestinal motility and small bowel growth, respectively. A case of a GLP1 and somatostatin-secreting NET has been reported presenting with reactive hypoglycaemia and hyperglycaemia subsequently cured by surgery (Todd et al. 2003). Another case of a well-differentiated NET of unknown primary origin presenting with diffuse metastases, constipation and nocturnal itching with positive immunostaining for GLP1, GLP2 and polypeptide YY (PYY) has been described. Jejunal biopsy demonstrated marked intestinal mucosal hypertrophy. High-performance liquid chromatography (HPLC) analysis combined with radioimmunoassay (RIA) of tumour and serum extracts revealed that the tumour was secreting and releasing GLP1 and GLP2, as well as PYY (Byrne et al. 2001). Ectopic secretion of ghrelin, in the serum of a patient with a pNET has been reported, as well as a carcinoid of the stomach

Published by Bioscientifica Ltd. 
albeit without clinical symptoms (Corbetta et al. 2003, Tsolakis et al. 2004). Somasundaram and coworkers report the case of an ACTH-secreting thymic carcinoid causing Cushing's syndrome, with histopathological features of gastrin over-secretion and Zollinger-Ellison syndrome (Somasundaram et al. 2013).

Other rare peptide hormones Ectopic calcitonin over-secretion is rare. A case of a SCLC presenting with dual PNS including over-secretion of ACTH and calcitonin has been described (Coners et al. 2011). Presenting symptoms included metabolic alkalosis with hypokalaemia, hypocalcaemia, hypomagnesaemia, hypophosphataemia, hyperglycaemia and profound diarrhoea (Coners et al. 2011). There are several other cases of ectopic calcitonin secretion by SCLC, LCLC or lung carcinoids (Kelley et al. 1994, Machens et al. 2000, Cvijovic et al. 2013).

Tumour-induced osteomalacia (TIO) is a rare PNS manifested with bone and muscular pains, bone fractures, and sometimes loss of height and weight (Dadoniene et al. 2016). The first evidence of a circulating factor that could cause phosphate wasting in humans was described when a tumour transplanted into nude mice caused hypophosphataemia (Miyauchi et al. 1988). Fibroblast growth factor FGF23 is secreted by the bones and was first identified as the phosphaturic agent when mutations in FGF23 gene were linked to autosomal dominant hypophosphataemic rickets (ADHR) (White et al. 2001). In cases of TIO, FGF23 (FGF23/Klotho system) secretion is much higher leading to dysregulation of the FGF23 degradation pathway (Hannan et al. 2008). Tumours usually bearing the ability to over-secrete FGF23 are generally of mesenchymal origin, but there are cases of an adenocarcinoma of the colon and prostate (Ramon et al. 2011, Mak et al. 2012, Leaf et al. 2013). FGF23 measurements combined with ${ }^{18}$ FDG PET/CT SCAN can be a decisive tool in cases of TIO, and is likely going to be of considerable importance for facilitating early diagnosis and follow-up (Dupond et al. 2005). Current management of TIO involves tumour resection. However, the development of a humanised anti-FGF23 antibody for adult patients with X-linked hypophosphataemic rickets (XLHR) may be useful for patients with TIO with similar pathogenesis to that of XLHR (Kinoshita \& Fukumoto 2014).

Hypertrophic osteoarthropathy (HOA) is a syndrome characterised by proliferative changes in the skin and skeleton. In addition, it may also comprise of proliferative periostitis of the long bones, oligo- or polysynovitis and digital clubbing (Dubrey et al. 2016). There are two types of hypertrophic osteoarthropathy: primary and secondary. Only $3-5 \%$ of patients have primary HOA while the remaining 95-97\% have secondary HOA, commonly associated with many disease conditions of the cardiovascular system and hepatobiliary gastrointestinal system as well as in malignancies, including neuroendocrine carcinomas of the oesophagus and lungs (El Bakkal et al. 2011, Saif \& Vethody et al. 2016). Current evidence favours a pathology based on inadequate uptake or metabolism of prostaglandin E2.

Ectopic oxytocin secretion is a very rare PNS but has been reported in cases of SCLC (Shigetomi et al. 1980, Wilson \& Ngsee 1980). A case of an SCLC tumour cell line from a patient with PN hyponatraemia was shown to ectopically produce, process and secrete ANP in the same immunoreactive form as the biologically active molecule. It apparently contained an enzyme that could cleave precursors at the same amino acid sequences needed to produce ANP-(S99-Y126) from pro-ANP (Johnson et al. 1997). The recent demonstration of human placental lactogen (hPL) in serum samples of 12 patients with testicular malignancy and highly elevated levels of holohCG (mean: $42.490 \mathrm{ng} / \mathrm{mL}$ ) suggest an auto/paracrine function of this molecule (Madersbacher et al. 1998). Cases of SCLCs and phaeochromocytoma have also been reported secreting hPL (Kaltsas et al. 2010).

There is evidence that glomus tumours of the skull base (head-and-neck paragangliomas) may secrete neuropeptides, such as cholecystokinin, in addition to catecholamines (Jackson et al. 1989). High circulating levels of cholecystokinin associated with these tumours may be responsible for the unexplained phenomenon of prolonged post-operative ileus (Jackson et al. 1989).

\section{Endocrine paraneoplastic syndromes secondary to the secretion of non-peptide agents}

Cytokines In recent years, increasing evidence has been adduced that phaeochromocytomas are capable of secreting cytokines, mainly interleukin-1 (IL1) (Bornstein et al. 1996, Liu et al. 2000), IL6 (Shimizu et al. 2001), tumour necrosis factor- $\alpha$ (TNFa) and interferon- $\gamma$ (IFNg) (Tirone et al. 1989). In such cases marked inflammatory reactions and pyrexia were improved on either non-steroidal anti-inflammatory drugs (NSAIDs) or corticosteroids, but subsided after adrenalectomy (Minetto et al. 2003). Non-endocrine tumours producing cytokines are usually of mesenchymal origin; a recent case 
reported an angiomatoid fibrous histiocytoma presenting with severe inflammatory symptoms, being immunohistopathologically positive for IL-6 and Tyr705phosphorylation of signal transducer and activator of transcription 3 (STAT3) (Akiyama et al. 2015). The EWSR1CREB1 fusion gene detected in the tumour led to continuous activation of CREB1 and IL6 production because the promoter region of IL6 has a CREB binding site (Akiyama et al. 2015).

\section{Steroid and other endocrine PNS related} compounds A number of mesenchymal cells can differentiate into steroidogenic cells following ectopic expression of nuclear factor (NR) 5A subfamily proteins, steroidogenic factor-1 and liver receptor homolog 1 (Yazawa et al. 2016). The ability of certain cells to differentiate into others may represent one of the mechanisms accounting for the development of PNS. This could be the underlying reason for the rare cases of steroid-secreting hormones leading to PNS from tissues other than the adrenal and the gonads (Yazawa et al. 2016).

Paraneoplastic hyperaldosteronism has been described in a patient with ovarian cancer and also in cases of Non-Hodgkin's lymphoma (NHL) (Todesco et al. 1975, Mulatero et al. 2001). It has been suggested that paraneoplastic hyperaldosteronism could be secondary to the expression of the CYP11B2 gene (Mulatero et al. 2001). In a patient with NHL and unexplained hypertension, RNA extraction from a lymph node demonstrated increased CYP11B2 mRNA expression, confirming that hyperaldosteronism was paraneoplastic (Mulatero et al. 2001). Struma ovarii is a rare subtype of ovarian cancer representing $<1 \%$ of all ovarian malignancies (Lara et al. 2016). It represents a monodermal teratoma composed of mature thyroid tissue; thyroid tissue must comprise more than 50 percent of the overall ovarian tissue to be classified as a struma ovarii. The diagnosis is usually made on clinical presentations including symptoms of overactive thyroid function. The rate of recurrence is high and in the majority of patients with malignant struma ovarii adjuvant chemotherapy is necessary. The mechanism underlying the functioning status of the tumour is still unclear, but the presence of thyroid stimulating hormone receptor (TSHr) is thought to play a role. It represents the only known malignancy that secretes ectopic TSH (Lara et al. 2016). Gestational trophoblastic diseases comprise hydatidiform moles, invasive moles, choriocarcinomas and placental site trophoblastic tumours. Hydatidiform moles and choriocarcinomas that secrete high amounts of hCG can cause hyperthyroidism (Kopp 2010).

\section{Conclusions}

As the incidence of several types of neoplasms and in particular NETs increases, and as these patients live longer, the incidence of PNS will most probably increase. These syndromes affect the presentation, clinical course and treatment of such patients. As a result of recent diagnostic and therapeutic advances, many PNS are currently well defined, and some effective treatment options are evolving. The ability to recognise and treat PNS may have a substantial effect on clinical outcomes, ranging from earlier cancer diagnosis, to improved quality of life, to increased delivery of tumour-directed therapy. Furthermore, on-going research into these disorders may shed light on mechanisms of tumour development, maintenance and proliferation. However, as the exact prevalence of PNS is still a matter of debate, registration of these syndromes seems imperative to help identify their exact aetiology and their effect on the disease process.

\section{Declaration of interest}

GKD, A A, M O W and H S R declare that there is no conflict of interest that could be perceived as prejudicing the impartiality of this review. $\mathrm{G} \mathrm{K}$ and A $G$ have received advisory board and lecture fees from pharmaceutical companies.

\section{Funding}

This work did not receive any specific grant from any funding agency in the public, commercial or not-for-profit sector.

Author contribution statement

The authors of this manuscript contributed equally to its creation.

\section{References}

Abraham P, Ralston SH, Hewison M, Fraser WD \& Bevan JS 2002 Presentation of a PTHrP-secreting pancreatic neuroendocrine tumour, with hypercalcaemic crisis, pre-eclampsia, and renal failure. Journal of Postgraduate Medicine 78 752-753. (doi:10.1136/ pmj.78.926.752)

Agarwala SS 1996 Paraneoplastic syndromes. Medical Clinics of North America 80 173-184. (doi:10.1016/S0025-7125(05)70434-X)

Akiyama M, Yamaoka M, Mikami-Terao Y, Yokoi K, Inoue T, Hiramatsu T, Ashizuka S, Yoshizawa J, Katagi H, Ikegami M, et al. 2015 Paraneoplastic syndrome of angiomatoid fibrous histiocytoma may be caused by EWSR1-CREB1 fusion-induced excessive interleukin-6 production. Journal of Pediatric Hematology/Oncology 37 554-559. (doi:10.1097/MPH.0000000000000390)
(C) 2017 Society for Endocrinology Printed in Great Britain
Published by Bioscientifica Ltd 
Baijens LW \& Manni JJ 2006 Paraneoplastic syndromes in patients with primary malignancies of the head and neck: four cases and a review of the literature. European Archives of Oto-Rhino-Laryngology 263 32-36. (doi:10.1007/s00405-005-0942-1)

Ballav C, Naziat A, Mihai R, Karavitaki N, Ansorge O \& Grossman AB 2012 Mini-review: pheochromocytomas causing the ectopic ACTH syndrome. Endocrine 42 69-73. (doi:10.1007/s12020-012-9646-7)

Barbosa SL, Rodien P, Leboulleux S, Niccoli-Sire P, Kraimps JL, Caron P, Archambeaud-Mouveroux F, Conte-Devolx B, Rohmer V \& Groupe d'Etude des Tumeurs Endocrines 2005 Ectopic adrenocorticotropic hormone-syndrome in medullary carcinoma of the thyroid: a retrospective analysis and review of the literature. Thyroid $\mathbf{1 5}$ 618-623. (doi:10.1089/thy.2005.15.618)

Battocchio M, Zatelli MC, Chiarelli S, Trento M, Ambrosio MR, Pasquali C, De Carlo E, Dassie F, Mioni R, Rebellato A, et al. 2015 Ovarian tumors secreting insulin. Endocrine 49 611-619. (doi:10.1007/s12020015-0605-y)

Beckers MM, Slee PH \& van Doorn J 2003 Hypoglycaemia in patient with a gastrointestinal stromal tumour. Clinical Endocrinology 59 402-404. (doi:10.1046/j1365-2265.2003.01848.x)

Behrendt CE, Tumyan L, Gonser L, Shaw SL, Vora L, Paz IB, Ellenhorn JD \& Yim JH 2014 Evaluation of expert criteria for preoperative magnetic resonance imaging of newly diagnosed breast cancer. Breast 23 341-345. (doi:10.1016/j.breast.2014.01.005)

Benjamin MS, Drucker EA, McLoud TC \& Shepard JA 2003 Small pulmonary nodules: detection at chest CT and outcome. Radiology 226 489-493. (doi:10.1148/radiol.2262010556)

Biermasz NR, Smit JW, Pereira AM, Frolich M, Romijn JA \& Roelfsema F 2007 Acromegaly caused by growth hormone-releasing hormoneproducing tumors: long-term observational studies in three patients. Pituitary 10 237-249. (doi:10.1007/s11102-007-0045-7)

Bollanti L, Riondino G \& Strollo F 2001 Endocrine paraneoplastic syndromes with special reference to the elderly. Endocrine $\mathbf{1 4}$ 151-157. (doi:10.1385/ENDO:14:2:151)

Bornstein SR, Ehrhart-Bornstein M, Gonzalez-Hernandez J, Schroder S \& Scherbaum WA 1996 Expression of interleukin-1 in human pheochromocytoma. Journal of Endocrinological Investigation 19 693-698. (doi:10.1007/BF03349041)

Borson-Chazot F, Garby L, Raverot G, Claustrat F, Raverot V, Sassolas G \& GTE Group 2012 Acromegaly induced by ectopic secretion of GHRH: a review 30 years after GHRH discovery. Journal of Endocrinological Investigation 73 497-502. (doi:10.1016/j. ando.2012.09.004)

Braunstein GD, Bridson WE, Glass A, Hull EW \& McIntire KR 1972 In vivo and in vitro production of human chorionic gonadotropin and a-feteoprotein by a virilising hepatoblastoma. Journal of Clinical Endocrinology and Metabolism 35 857-862. (doi:10.1210/jcem-35-6857)

Brignardello E, Manti R, Papotti M, Allia E, Campra D, Isolato G, Cassinis MC, Fronda G \& Boccuzzi G 2004 Ectopic secretion of LH by an endocrine pancreatic tumor. Journal of Endocrinological Investigation 27 361-365. (doi:10.1007/BF03351063)

Brzozowska MM, Wolmarans L \& Conaglen JV 2009 Hypercalcaemia caused by a carcinoid tumour. Journal of Internal Medicine 39 415-418. (doi:10.1111/j.1445-5994.2009.01934.x)

Burgos J, Cobos P, Vidaurrazaga N, Prieto B, Ocerin I \& Matorras R 2009 Ovarian hyperstimulation secondary to ectopic secretion of folliclestimulating hormone. Literature review prompted by a case. Fertility and Sterility 92 1168.e5-1168.e8. (doi:10.1016/j. fertnstert.2009.06.023)

Butler PW, Cochran CS, Merino MJ, Nguyen DM, Schrump DS \& Gorden P 2012 Ectopic growth hormone-releasing hormone secretion by a bronchial carcinoid tumor: clinical experience following tumor resection and long-acting octreotide therapy. Pituitary 15 260-265. (doi:10.1007/s11102-010-0226-7)
Byrne MM, McGregor GP, Barth P, Rothmund M, Goke B \& Arnold R 2001 Intestinal proliferation and delayed intestinal transit in a patient with a GLP-1-, GLP-2- and PYY producing neuroendocrine carcinoma. Digestion 63 61-68. (doi:10.1159/000051874)

Castillo JJ, Vincent M \& Justice E 2012 Diagnosis and management of hyponatremia in cancer patients. Oncologist 17 756-765. (doi:10.1634/theoncologist.2011-0400)

Chrisoulidou A, Pazaitou-Panayiotou K, Georgiou E, Boudina M, Kontogeorgos G, Iakovou I, Efstratiou I, Patakiouta F \& Vainas I 2008 Ectopic Cushing's syndrome due to CRH secreting liver metastasis in a patient with medullary thyroid carcinoma. Hormones 7 259-262.

Christofides ND, Stephanou A, Suzuki H, Yiangou Y \& Bloom SR 1984 Distribution of immunoreactive growth hormone-releasing hormone in the human brain and intestine and its production by tumors. Journal of Clinical Endocrinology and Metabolism 59 747-751. (doi:10.1210/jcem-59-4-747)

Colak Ozbey N, Kapran Y, Bozbora A, Erbil Y, Tascioglu C \& Asa SL 2009 Ectopic growth hormone-releasing hormone secretion by a neuroendocrine tumor causing acromegaly: long-term follow-up results. Endocrine Pathology 20 127-132. (doi:10.1007/s12022-0099067-1)

Collins MT, Skarulis MC, Bilezikian JP, Silverberg SJ, Spiegel AM \& Marx SJ 1998 Treatment of hypercalcemia secondary to parathyroid carcinoma with a novel calcimimetic agent. Journal of Clinical Endocrinology and Metabolism 83 1083-1088. (doi:10.1210/ jcem.83.4.4726)

Coners K, Woods SE \& Webb M 2011 Dual paraneoplastic syndromes in a patient with small cell lung cancer: a case report. Journal of International Medical Case Reports 5 318. (doi:10.1186/1752-1947-5318)

Corbetta S, Peracchi M, Cappiello V, Lania A, Lauri E, Vago L, BeckPeccoz P \& Spada A 2003 Circulating ghrelin levels in patients with pancreatic and gastrointestinal neuroendocrine tumors: identification of one pancreatic ghrelinoma. Journal of Endocrinological Investigation 88 3117-3120. (doi:10.1210/jc.2002-021842)

Crona J, Norlén O, Antonodimitrakis P, Welin S, Stålberg P \& Eriksson B 2016 Multiple and secondary hormone secretion in patients with metastatic pancreatic neuroendocrine tumours. Journal of Clinical Endocrinology and Metabolism 101 445-452. (doi:10.1210/jc.20152436)

Cvijovic G, Micic D, Kendereski A, Zoric S, Sumarac-Dumanovic M, Tatic S, Trivic A, Pejkovic-Stamenkovic D \& Jeremic D 2013 Ectopic calcitonin secretion in a woman with large cell neuroendocrine lung carcinoma. Hormones 12 584-590. (doi:10.14310/horm.2002.1447)

Dadoniene J, Miglinas M, Miltiniene D, Vajauskas D, Seinin D, Butenas P \& Kacergius T 2016 Tumour-induced osteomalacia: a literature review and a case report. World Journal of Surgical Oncology 144. (doi:10.1186/s12957-015-0763-7)

Dayal Y, Lin HD, Tallberg K, Reichlin S, DeLellis RA \& Wolfe HJ 1986 Immunocytochemical demonstration of growth hormone-releasing factor in gastrointestinal and pancreatic endocrine tumors. American Journal of Clinical Pathology 85 13-20. (doi:10.1093/ajcp/85.1.13)

De Groot JW, Rikhof B, van Doorn J, Bilo HJ, Alleman MA, Honkoop AH \& Van der Graaf WT 2007 Non-islet cell tumour-induced hypoglycaemia: a review of the literature including two new cases. Endocrine-Related Cancer 14 979-993. (doi:10.1677/ERC-07-0161)

De Rooij M, Crienen S, Witjes JA, Barentsz JO, Rovers MM \& Grutters JP 2014 Cost-effectiveness of magnetic resonance (MR) imaging and MR-guided targeted biopsy versus systematic transrectal ultrasoundguided biopsy in diagnosing prostate cancer: a modelling study from a health care perspective. European Urology 66 430-436. (doi:10.1016/j.eururo.2013.12.012)

DeLellis RA \& Xia L 2003 Paraneoplastic endocrine syndromes: a review. Endocrine Pathology 14 303-317. (doi:10.1385/EP:14:4:303) http://erc.endocrinology-journals.org

DOI: 10.1530/ERC-17-0036
() 2017 Society for Endocrinology Printed in Great Britain
Published by Bioscientifica Ltd 
Di Iorgi N, Secco A, Napoli F, Tinelli C, Calcagno A, Fratangeli N, Ambrosini L, Rossi A, Lorini R \& Maghnie M 2007 Deterioration of growth hormone $(\mathrm{GH})$ response and anterior pituitary function in young adults with childhood-onset GH deficiency and ectopic posterior pituitary: a two-year prospective follow-up study. Journal of Clinical Endocrinology and Metabolism 92 3875-3884. (doi:10.1210/ jc.2007-1081)

Dimitriadis GK, Gopalakrishnan K, Rao R, Grammatopoulos DK, Randeva HS, Weickert MO \& Murthy N 2015 Severe paraneoplastic hypoglycaemia secondary to a gastrointestinal stromal tumour masquerading as a stroke. Endocrinology, Diabetes and Metabolism Case Reports 2015 EDM150062. (doi:10.1530/EDM-15-0062)

Dimitriadis GK, Weickert MO, Randeva HS, Kaltsas G \& Grossman A 2016 Medical management of secretory syndromes related to gastroenteropancreatci neuroendocrine tumours. Endocrine-Related Cancer 23 R423-R436. (doi:10.1530/ERC-16-0200)

Dimitriadis GK, Kaltsas G, Ghobara T, Sinha B, Drakou EE, Gopalakrishnan K, Kosmas C, Keay SD, Grammatopoulos DK \& Randeva HS 2017 Hypertestosteronemia and infertility from a mediastinal extragonadal germ cell tumor. American Journal of Medicine [in press]. (doi:10.1016/j.amjmed.2017.01.010)

Donovan PJ, Achong N, Griffin K, Galligan J, Pretorius CJ \& McLeod DS 2015 PTHrP-mediated hypercalcemia: causes and survival in 138 patients. Journal of Clinical Endocrinology and Metabolism 1002024 2029. (doi:10.1210/jc.2014-4250)

Dubrey S, Pal S, Singh S \& Karagiannis G 2016 Digital clubbing: forms, associations and pathophysiology. British Journal of Hospital Medicine 77 403-408. (doi:10.12968/hmed.2016.77.7.403)

Dupond JL, Mahammedi H, Prié D, Collin F, Gil H, Blagosklonov O, Ricbourg B, Meaux-Ruault N \& Kantelip B 2005 Oncogenic osteomalacia: diagnostic importance of fibroblast growth factor 23 and F-18 fluorodeoxyglucose PET/CT scan for the diagnosis and follow-up in one case. Bone 36 375-378. (doi:10.1016/j. bone.2005.01.001)

El Bakkal A, Idrissi R, Meziane M, Mikou O, Sekal M, Belghiti H, Bennani A, Znati K, Amarti A, Karkos F, et al. 2011 Tripe palms and a hypertrophic osteoarthropathy syndrome revealing a neuroendocrine carcinoma of the lung. Annales de Dermatologie et de Vénéréologie 138 $668-672$.

Ellison DH \& Berl T 2007 The syndrome of inappropriate antidiuresis. New England Journal of Medicine 356 2064-2072. (doi:10.1056/ NEJMcp066837)

Fainstein Day P, Frohman L, Garcia Riveloo H, Reubi JC, Sevlever G, Glerean M, Fernandez Gianotti T, Pietrani M, Rabadan A, Racioppi S, et al. 2007 Ectopic growth hormone-releasing hormone secretion by a metastatic bronchial tumor: a case with a non hypophysial intracranial tumor that shrank during long acting octreotide treatment. Pituitary 10 311-319. (doi:10.1007/s11102-007-0019-9)

Fröberg AC, De Jong M, Nock BA, Breeman WA, Erion JL, Maina T, Verdijsseldonck M, De Herder WW, Van der Lugt A, Kooij PP, et al. 2009 Comparison of three radiolabelled peptide analogues for CCK-2 receptor scintigraphy in medullary thyroid carcinoma. European Journal of Nuclear Medicine 36 1265-1272. (doi:10.1007/s00259-0091098-9)

Furrer J, Hattenschwiler A, Komminoth P, Pfammatter T \& Wiesli P 2001 Carcinoid syndrome, acromegaly, and hypoglycaemia due to an insulin-secreting neuroendocrine tumor of the liver. Journal of Clinical Endocrinology and Metabolism 86 2227-2230. (doi:10.1210/ jcem.86.5.7461)

Galindo RJ, Romao I, Valsamis A, Weinerman S \& Harris YT 2016 Hypercalcemia of malignancy and colorectal cancer. World Journal of Oncology 7 5-12. (doi:10.14740/wjon953w)

Ganguly A, Gribble J, Tune B, Kempson RL \& Luetscher JA 1973 Renin secreting Wilms' tumor with severe hypertension: report of a case and brief review of renin-secreting tumor. Annals of Internal Medicine 79 835-837.
Garby L, Caron P, Claustrat F, Chanson P, Tabarin A, Rohmer V, Arnault G, Bonnet F, Chabre O, Christin-Maitre S, et al. 2012 Clinical characteristic and outcome of acromegaly induced by ectopic secretion of growth hormone-releasing hormone (GHRH): a French nationwide series of 21 cases. Journal of Clinical Endocrinology and Metabolism 97 2093-2104. (doi:10.1210/jc.2011-2930)

Gilmore JL, Gonterman RM, Menon K, Lorch G, Riese DJ, Robling A \& Foley J 2009 Reconstitution of amphiregulin-epidermal growth factor receptor signaling in lung squamous cell carcinomas activates PTHrP gene expression and contributes to cancer-mediated diseases of the bone. Molecular Cancer Research 7 1714-1728. (doi:10.1158/15417786.MCR-09-0131)

Gotthardt M, Bleeker-Rovers CP, Boerman OC \& Oyen WJ 2010 Imaging of inflammation by PET, conventional scintigraphy, and other imaging techniques. Journal of Nuclear Medicine 51 1937-1949.

Granot Z \& Fridlender ZG 2015 Plasticity beyond cancer cells and the 'immunosuppressive switch'. Cancer Research 75 4441-4445. (doi:10.1158/0008-5472.CAN-15-1502)

Grant P, Ayuk J, Bouloux PM, Cohen M, Cranston I, Murray RD, Rees A, Thatcher N \& Grossman A 2015 The diagnosis and management of in-patient hyponatraemia and SIADH. European Journal of Clinical Investigation 45 888-894. (doi:10.1111/eci.12465)

Grohé C, Berardi R \& Burst V 2015 Hyponatraemia - SIADH in lung cancer diagnostic and treatment algorithms. Critical Reviews in Oncology/Hematology 96 1-8. (doi:10.1016/j.critrevonc.2015.04.005)

Guichard A \& Vignon G La 1949 Polyradiculoneurite cancereuse metastatique. Journal de Médecine de Lyon Impact and Description 30 197-207.

Hamberg P, De Jong FA, Boonstra JG, Van Doorn J, Verweij J \& Sleijfer S 2006 Non-islet-cell tumor induced hypoglycaemia in patients with advanced gastrointestinal stromal tumor possibly worsened by imatinib. Journal of Clinical Oncology 24 e30-e31. (doi:10.1200/ JCO.2006.065318)

Hannan FM, Athanasou NA, Teh J, Gibbons CLMH, Shine B \& Thakker RV 2008 Oncogenic hypophosphataemic osteomalacia: biomarker roles of fibroblast growth factor 23, 1,25-dihydroxyvitamin D3 and lymphatic vessel endothelial hyaluronan receptor 1. European Journal of Endocrinology 158 265-271. (doi:10.1530/EJE-07-0485)

Hiraki A, Ueoka H, Takata I, Gemba K, Bessho A, Segawa Y, Kiura K, Eguchi K, Yoneda T, Tanimoto M, et al. 2004 Hypercalcemialeukocytosis syndrome associated with lung cancer. Lung Cancer $\mathbf{4 3}$ 301-307. (doi:10.1016/j.lungcan.2003.09.006)

Hofland LJ \& Lamberts SW 2001 Somatostatin receptor subtype expression in human tumors. Annals of Oncology 12 (Supplement 2) S31-S36. (doi:10.1093/annonc/12.suppl_2.S31)

Hong H, Sun J \& Cai W 2008 Anatomical and molecular imaging of skin cancer. Clinical, Cosmetic and Investigational Dermatology 1 1-17.

Howlett TA, Drury PL, Perry L, Doniach I, Rees LH \& Besser GM 1986 Diagnosis and management of ACTH-dependent Cushing's syndrome: comparison of the features in ectopic and pituitary ACTH production. Clinical Endocrinology 24 699-713. (doi:10.1111/ j.1365-2265.1986.tb01667.x)

Iglesias P \& Díez JJ 2014 Management of endocrine disease: a clinical update on tumor-induced hypoglycemia. European Journal of Endocrinology 170 R147-R157. (doi:10.1530/EJE-13-1012)

Ilias I, Torpy DJ, Pacak K, Mullen N, Wesley RA \& Nieman LK 2005 Cushing's syndrome due to ectopic corticotrophin secretion: twenty years' experience at the National Institutes of Health. Journal of Clinical Endocrinology and Metabolism 90 4955-4962. (doi:10.1210/ jc.2004-2527)

Isidori AM, Kaltsas GA, Pozza C, Frajese V, Newell-Price J, Reznek RH, Jenkins PJ, Monson JP, Grossman AB \& Besser GM 2006 The ectopic adrenocorticotropin syndrome: clinical features, diagnosis, management, and long-term follow-up. Journal of Clinical Endocrinology and Metabolism 91 371-377. (doi:10.1210/jc.20051542) 
Jackson CG, Gulya AJ, Knox GW, Glasscock ME 3rd, Pensak ML, Poe DS \& Johnson GD 1989 A paraneoplastic syndrome associated with glomus tumors of the skull base? Early observations. Otolaryngology: Head and Neck Surgery 100 583-587.

Jacobson AF, Deng H, Lombard J, Lessig HJ \& Black RR 2010 123I-metaiodobenzylguanidine scintigraphy for the detection of neuroblastoma and pheochromocytoma: results of a meta-analysis. Journal of Clinical Endocrinology and Metabolism 95 2596-2606. (doi:10.1210/jc.2009-2604)

Jia R, Sulentic P, Xu JM \& Grossman AB 2017 Thymic neuroendocrine neoplasms: biological behaviour and therapy. Neuroendocrinology [in press]. (doi:10.1159/000472255)

Johnson BE, Damodaran A, Rushin J, Gross A, Le PT, Chen HC \& Harris RB 1997 Ectopic production and processing of atrial natriuretic peptide in a small cell lung carcinoma cell line and tumor from a patient with hyponatremia. Cancer 79 35-44. (doi:10.1002/ (SICI)1097-0142(19970101)79:1<35::AID-CNCR6>3.0.CO;2-L)

Kaltsas G, Korbonits M, Heintz E, Mukherjee JJ, Jenkins PJ, Chew SL, Reznek R, Monson JP, Besser GM, Foley R, et al. 2001 Comparison of somatostatin analog and meta-iodobenzylguanidine radionuclides in the diagnosis and localization of advanced neuroendocrine tumors. Journal of Clinical Endocrinology and Metabolism 86 895-902. (doi:10.1210/jcem.86.2.7194)

Kaltsas GA, Besser GM \& Grossman AB 2004 The diagnosis and medical management of advanced neuroendocrine tumors. Endocrine Reviews 25 458-511. (doi:10.1210/er.2003-0014)

Kaltsas G, Androulakis II, de Herder WW \& Grossman AB 2010 Paraneoplastic syndromes secondary to neuroendocrine tumours. Endocrine-Related Cancer 17 R173-R193. (doi:10.1677/ERC-10-0024)

Kamp K, Feelders RA, Van Alrichem RC, De Rijke YB, Van Nederveen FH, Kwekkeboom DJ \& De Herder WW 2014 Parathyroid hormonerelated peptide (PTHrP) secretion by gastroenteropancreatic neuroendocrine tumors (GEP-NETs): clinical features, diagnosis, management, and follow-up. Journal of Clinical Endocrinology and Metabolism 99 3060-3069. (doi:10.1210/jc.2014-1315)

Kamp K, Alwani RA, Korpershoek E, Franssen GJ, De Herder WW \& Feelders RA 2016 Prevalence and clinical features of the ectopic ACTH syndrome in patients with gastroenteropancreatic and thoracic neuroendocrine tumors. European Journal of Endocrinology 174 271-280. (doi:10.1530/EJE-15-0968)

Kampfenkel T, Baraniskin A, Teschendorf C, Schmiegel W \& Massenkeil G 2010 A rare case of chronic lymphocytic leukemia with hypercalcemia induced by elevated parathyroid hormone-related peptides. Acta Haematologica 124 57-60. (doi:10.1159/000314646)

Kandil E, Noureldine S, Khalek MA, Daroca P \& Friedlander P 2011 Ectopic secretion of parathyroid hormone in a neuroendocrine tumor: a case report and review of the literature. International Journal of Clinical and Experimental Medicine 4 234-240.

Keffer JH 1996 Endocrinopathy and ectopic hormones in malignancy. Hematology/Oncology Clinics of North America 10 811-823. (doi:10.1016/S0889-8588(05)70370-1)

Kekelidze M, D’Errico L, Pansini M, Tyndall A \& Hohmann J 2013 Colorectal cancer: current imaging methods and future perspectives for the diagnosis, staging and therapeutic response evaluation. World Journal of Gastroenterology 19 8502-8514. (doi:10.3748/wjg.v19.i46.8502)

Kelley MJ, Becker KL, Rushin JM, Venzon D, Phelps R, Ihde DC, Bliss DP Jr, Melby K, Snider RH \& Johnson BE 1994 Calcitonin elevation in small cell lung cancer without ectopic production. American Journal of Respiratory and Critical Care Medicine 149 183-190. (doi:10.1164/ ajrccm.149.1.8111580)

Kim SW, Lee SE, Oh YL, Kim S, Park SH \& Kim JH 2016 Nonislet cell tumor hypoglycaemia in a patient with adrenal cortical carcinoma. Case Reports in Endocrinology 20165731417.

Kinoshita Y \& Fukumoto S 2014 Anti-FGF23 antibody therapy for patients with tumor-induced osteomalacia. Clinical Calcium $\mathbf{2 4}$ 1217-1222.
Kopp P 2010 Thyrotoxicosis of other etiologies. In Endotext. Eds De Groot LJ, Chrousos G, Dungan K, et al. South Dartmouth, MA, USA: MDText.com, Inc. (available at: https://www.ncbi.nlm.nih.gov/ books/NBK285562/)

Korevaar T, Ragazzoni F, Weaver A, Karavitaki N \& Grossman AB 2014 IGF2-induced hypoglycaemia unresponsive to everolimus. Quarterly Journal of Medicine 107 297-300. (doi:10.1093/qjmed/hcr249)

Kwekkeboom DJ, Krenning EP, Scheidhauer K, Lewigton V, Lebtahi R, Grossman AB, Vitek P, Sundin A \& Plockinger U 2009 ENETS Consensus Guidelines for the standards of care in neuroendocrine tumors: somatostatin receptor imaging with ${ }^{111}$ In-Pentreotide. Neuroendocrinology 90 184-189. (doi:10.1159/000225946)

Lara C, Cuenca D, Salame L, Padilla-Longoria R \& Mercado M 2016 A hormonally active malignant struma ovarii. Case Reports in Medicine 20162643470.

Leaf DE, Pereira RC, Bazari H \& Jüppner H 2013 Oncogenic osteomalacia due to FGF23-expressing colon adenocarcinoma. Journal of Clinical Endocrinology and Metabolism 98 887-891. (doi:10.1210/jc.2012-3473)

Lee HJ, Hyun JS, Jang HS, Sul H \& Park SG 2014 Paraneoplastic secondary hypertension due to a renin-secreting desmoplastic small round cell tumor: a case report. Oncology Letters 8 1986-1992.

Li WY, Liu XD, Li WN, Donq SY, Qu XH, Gonq SL, Shao MR \& Zhang L 2016 Paraneoplastic Cushing's syndrome associated with bronchopulmonay carcinoid tumor in youth: a case report and review of the literature. Oncology Letters 12 69-72.

Liu MT, Huang HM, Jeng KC, Ou SC \& Kuo JS 2000 Induction of cytokine genes and IL-1alpha by chemical hypoxia in PC12 cells. Life Science 67 2147-2157. (doi:10.1016/S0024-3205(00)00811-0)

Lock KY, Lau IT, Yeung CK \& Chan CP 2014 An unusual cause of acromegaly. Hong Kong Medical Journal 20 331-334. (doi:10.12809/ hkmj134044)

Lorch G, Gilmore JL, Koltz PF, Gonterman RM, Laughner R, Lewis DA, Konger RL, Nadella KS, Toribio RE, Rosol TJ, et al. 2007 Inhibition of epidermal growth factor receptor signalling reduces hypercalcaemia induced by human lung squamous-cell carcinoma in athymic mice. British Journal of Cancer 97 183-193. (doi:10.1038/sj.bjc.6603828)

Lumachi F, Brunello A, Roma A \& Basso U 2008 Medical treatment of malignancy-associated hypercalcemia. Current Medicinal Chemistry 15 415-421. (doi:10.2174/092986708783497346)

Machens A, Haedecke J, Holzhausen H-J, Thomusch O, Schneyer U \& Dralle H 2000 Differential diagnosis of calcitonin-secreting neuroendocrine carcinoma of the foregut by pentagastrin stimulation. Langenbeck's Archives of Surgery 385 398-401. (doi:10.1007/s004230000169)

Madersbacher S, Untergasser G, Gerth R, Hermann M, Schwärzler P, Dirnhofer S \& Berger P 1998 Reassessment of the role of human placental lactogen in physiological non-pregnant and pathological conditions. Experimental and Clinical Endocrinology and Diabetes 106 61-67. (doi:10.1055/s-0029-1211952)

Mak MP, Da Costa e Silva VT, Martin RM, Lerario AM, Yu L, Hoff PM \& De Castro G Jr 2012 Advanced prostate cancer as a cause of oncogenic osteomalacia: an underdiagnosed condition. Support Care Cancer 20 2195-2197. (doi:10.1007/s00520-012-1474-z)

Mantzoros CS, Suva LJ, Moses AC \& Spark R 1997 Intractable hypercalcaemia due to parathyroid hormone-related peptide secretion by a carcinoid tumour. Clinical Endocrinology 46 373-375. (doi:10.1046/j.1365-2265.1997.1090921.x)

Maragliano R, Vanoli A, Albarello L, Milione M, Basturk O, Klimstra DS, Wachtel A, Uccella S, Vicari E, Milesi M, et al. 2015 ACTH-secreting pancreatic neoplasms associated with Cushing syndrome: clinicopathologic study of 11 cases and review of the literature. American Journal of Surgical Pathology 39 374-382. (doi:10.1097/ PAS.0000000000000340)

Mehta H, Bahuva R \& Sadikot RT 2008 Lung cancer mimicking as pregnancy with pneumonia. Lung Cancer 61 416-419. (doi:10.1016/j. lungcan.2007.12.026)

Published by Bioscientifica Ltd. 
Melmed S 2006 Medical progress: acromegaly. New England Journal of Medicine 355 2558-2573. (doi:10.1056/NEJMra062453)

Menezes GL, Knuttel FM, Stehouwer BL, Pijnappel RM \& Van den Bosch MA 2014 Magnetic resonance imaging in breast cancer: a literature review and future perspectives. World Journal of Clinical Oncology $\mathbf{5}$ 61-70. (doi:10.5306/wjco.v5.i2.61)

Minetto M, Dovio A, Ventura M, Cappia S, Daffara F, Terzolo M \& Angeli A 2003 Interleukin-6 producing pheochromocytoma presenting with acute inflammatory syndrome. Journal of Endocrinological Investigation 26 453-457. (doi:10.1007/ BF03345202)

Miras AD, Mogford JT, Wright J, Mendoza NN, Xekouki P, Lakhani A, Pellegata NS, Stratakis CA, Roncaroli F \& Russell-Jones D 2015 Ovarian hyperstimulation from ectopic hypersecretion of follicle stimulating hormone. Lancet 385 392. (doi:10.1016/S01406736(14)62294-7)

Miyauchi A, Fukase M, Tsutsumi M \& Fujita T. Hemangiopericytomainduced osteomalacia: tumor transplantation in nude mice causes hypophosphatemia and tumor extracts inhibit renal 25-hydroxyvitamin D 1-hydroxylase activity 1988 Journal of Clinical Endocrinology and Metabolism 67 46-53. (doi:10.1210/jcem-67-1-46)

Modlin IM, Oberg K, Chung DC, Jensen RT, De Herder WW, Thakker RV, Caplin M, Delle FG, Kaltsas GA, Krenning EP, et al. 2008 Gastroenteropancreatic neuroendocrine tumours. Lancet Oncology 9 61-72. (doi:10.1016/S1470-2045(07)70410-2)

Modlin IM, Bodei L \& Kidd M 2016 Neuroendocrine tumor biomarkers: from monoanalytes to transcripts and algorithms. Best Practice and Research Clinical Endocrinology and Metabolism 30 59-77. (doi:10.1016/j.beem.2016.01.002)

Mohammed A, Shergill I \& Little B 2009 Management of metastatic renal cell carcinoma: current trends. Expert Review of Molecular Diagnostics 9 75-83. (doi:10.1586/14737159.9.1.75)

Morandi U, Casali C \& Rossi G 2006 Bronchial typical carcinoid tumors. Seminars in Thoracic and Cardiovascular Surgery 18 191-198. (doi:10.1053/j.semtcvs.2006.08.005)

Mulatero P, Rabbia F \& Veglio F 2001 Paraneoplastic hyperaldosteronism associated with non-Hodgkin's lymphoma. New England Journal of Medicine 344 1558-1559. (doi:10.1056/NEJM200105173442017)

Nagy-Mignotte H, Shestaeva O, Vignoud L, Guillem P, Ruckly S, Chabre O, Sakhri L, Duruisseaux M, Mousseau M, Timsit JF, et al. 2014 Prognostic impact of paraneoplastic Cushing's syndrome in smallcell lung cancer. Journal of Thoracic Oncology 9 497-505. (doi:10.1097/JTO.0000000000000116)

Nauck MA, Reinecke M, Perren A, Frystyk J, Berishvili G, Zwimpfer C, Figge AM, Flyvbjerg A, Lankisch PG, Blum WF, et al. 2007 Hypoglycemia due to paraneoplastic secretion of insulin-like growth factor-I in a patient with metastasizing large-cell carcinoma of the lung. Journal of Clinical Endocrinology and Metabolism 92 1600-1605. (doi:10.1210/jc.2006-2573)

Nayar MK, Lombard MG, Furlong NJ, McNulty SJ, Hardy KJ \& Vora J 2006 Diagnosis and management of nonislet cell tumor hypoglycemia: case series and review of the literature. Endocrinologist 16 227-230. (doi:10.1097/01.ten.0000226008.02412.0b)

Neary NM, Lopez-Chavez A, Abel BS, Boyce AM, Schaub N, Kwong K, Stratakis CA, Moran CA, Giaccone G \& Nieman LK 2012 Neuroendocrine ACTH-producing tumor of the thymus - experience with 12 patients over 25 years. Journal of Clinical Endocrinology and Metabolism 97 2223-2230. (doi:10.1210/jc.2011-3355)

Nella AA, Lodish MB, Fox E, Balis FM, Quezado MM, Whitcomb PO, Derdak J, Kebebew E, Widemann BC \& Stratakis CA 2014 Vandetanib successfully controls medullary thyroid cancer-related Cushing syndrome in an adolescent patient. Journal of Clinical Endocrinology and Metabolism 99 3055-3059. (doi:10.1210/jc.2013-4340)

Newell-Price J 2003 Proopiomelanocortin gene expression and DNA methylation: implications for Cushing's syndrome and beyond. Journal of Endocrinology 177 365-372. (doi:10.1677/joe.0.1770365)
Newell-Price J, Trainer P, Besser M \& Grossman A 1998 The diagnosis and differential diagnosis of Cushing's syndrome and pseudoCushing's states. Endocrine Reviews 19 647-672. (doi:10.1210/ er.19.5.647)

Newell-Price J, Bertagna X, Grossman AB \& Nieman LK 2006 Cushing's syndrome. Lancet 367 1605-1617. (doi:10.1016/S01406736(06)68699-6)

Nieman LK 2002 Medical therapy of Cushing's disease. Pituitary 5 77-82. (doi:10.1023/A:1022308429992)

Nieman LK, Biller BM, Findling JW, Murad MH, Newell-Price J, Savage MO, Tabarin A \& Endocrine Society 2015 Treatment of Cushing's syndrome: an Endocrine Society Clinical Practice Guideline. Journal of Clinical Endocrinology and Metabolism 100 2807-2831. (doi:10.1210/jc.2015-1818)

Nimalasena S, Freeman A \& Harland S 2008 Paraneoplastic Cushing's syndrome in prostate cancer: a difficult management problem. BJU International 101 424-427. (doi:10.1111/j.1464-410X.2007.07294.x)

Oberg K, Krenning E, Sundin A, Bodei L, Kidd M, Tesselaar M, Ambrosini V, Baum RP, Kulke M, Pavel M, et al. 2016 A Delphic consensus assessment: imaging and biomarkers in gastroenteropancreatic neuroendocrine tumor disease management. Endocrine Connections 5 174-187. (doi:10.1530/EC-16-0043)

Oldfield EH, Doppman JL, Nieman LK, Chrousos GP, Miller DL, Katz DA, Cutler GB Jr \& Loriaux DL 1991 Petrosal sinus sampling with and without corticotropin-releasing hormone for the differential diagnosis of Cushing's syndrome. New England Journal of Medicine 325 897-905. (doi:10.1056/NEJM199109263251301)

Otake S, Kikkawa T, Takizawa M, Oya J, Hanai K, Tanaka N, Miura J, Fukuda I, Kanzaki M, Sawada T, et al. 2015 Hypoglycemia observed on continuous glucose monitoring associated with IGF-2-producing solitary fibrous tumor. Journal of Clinical Endocrinology and Metabolism 100 2519-2524. (doi:10.1210/jc.2014-4534)

Pach D, Sowa-Staszczak A, Jabrocka-Hybel A, Stefańska A, Tomaszuk M, Mikołajczak R, Janota B, Trofimiuk-Müldner M, Przybylik-Mazurek E \& Hubalewska-Dydejczyk A 2013 Glucagon-like peptide-1 receptor imaging with [lys (40) (Ahx-HYNIC-(99m) Tc/EDDA)NH 2]-exendin-4 for the diagnosis of recurrence or dissemination of medullary thyroid cancer: a preliminary report. International Journal of Endocrinology 2013384508.

Pasquini E, Faustini-Fustini M, Sciarretta V, Saggese D, Roncaroli F, Serra D \& Frank G 2003 Ectopic TSH secreting pituitary adenoma of the vomerosphenoidal junction. European Journal of Endocrinology 148 253-257. (doi:10.1530/eje.0.1480253)

Pelosof LC \& Gerber DE 2010 Paraneoplastic syndromes: an approach to diagnosis and treatment. Mayo Clinic Proceedings 85 838-854. (doi:10.4065/mcp.2010.0099)

Piaditis G, Angellou A, Kontogeorgos G, Mazarakis N, Kounadi T, Kaltsas G, Vamvakidis K, Lloyd RV, Horvath E \& Kovacs K 2005 Ectopic bioactive luteinizing hormone secretion by a pancreatic endocrine tumor, manifested as luteinized granulosathecal cell tumor of the ovaries. Journal of Clinical Endocrinology and Metabolism 90 2097-2103. (doi:10.1210/jc.2003-032029)

Pierce ST 1993 Paraendocrine syndromes. Current Opinion in Oncology 5 639-645. (doi:10.1097/00001622-199307000-00004)

Preda V, Chen J, Karavitaki N \& Grossman AB 2012 The use of etomidate in the treatment of Cushing's syndrome. European Journal of Endocrinology 167 137-143.

Raftopoulos H 2007 Diagnosis and management of hyponatremia in cancer patients. Support Care Cancer 15 1341-1347. (doi:10.1007/ s00520-007-0309-9)

Ralston SH, Gallacher SJ, Patel U, Campbell J \& Boyle IT 1990 Cancer associated hypercalcemia: morbidity and mortality. Clinical experience in 126 treated patients. Annals of Internal Medicine 112 499-504. (doi:10.7326/0003-4819-112-7-499)

Ramkumar S, Dhingra A, Jyotsna V, Ganie MA, Das CJ, Seth A, Sharma MC \& Bal CS 2014 Ectopic insulin secreting neuroendocrine tumor

Published by Bioscientifica Ltd 
of kidney with recurrent hypoglycemia: a diagnostic dilemma. BMC Endocrine Disorders 14 36. (doi:10.1186/1472-6823-14-36)

Ramon I, Kleynen P, Valsamis J, Body JJ \& Karmali R 2011 Hypophosphatemia related to paraneoplastic Cushing syndrome in prostate cancer: cure after bilateral adrenalectomy. Calcified Tissue International 89 442-445. (doi:10.1007/s00223-011-9527-8)

Rikhof B, Van Doorn J, Suurmeijer AJ, Rautenberg MW, Groenen PJ, Verdijk MA, Jager PL, De Jong S, Gietema JA \& Van der Graaf WT 2009 Insulin-like growth factors and insulin-like growth factorbinding proteins in relation to disease status and incidence of hypoglycaemia in patients with a gastrointestinal stromal tumour. Annals of Oncology 20 1582-1588. (doi:10.1093/annonc/mdp038)

Rivera RT, Pasion SG, Wong DT, Fei YB \& Biswas DK 1989 Loss of tumorigenic potential by human lung tumor cells in the presence of antisense RNA specific to the ectopically synthesized alpha subunit of human chorionic gonadotropin. Journal of Cell Biology $\mathbf{1 0 8}$ 2423-2434. (doi:10.1083/jcb.108.6.2423)

Roberts JE, Spandorfer S, Fasouliotis SJ, Lin K \& Rosenwaks Z 2005 Spontaneous ovarian hyperstimulation caused by a folliclestimulating hormone-secreting pituitary adenoma. Fertility and Sterility 83 208-210. (doi:10.1016/j.fertnstert.2004.06.061)

Rosei CA, Giacomelli L, Salvetti M, Paini A, Corbellini C, Tiberio G \& Muiesan ML 2015 Advantages of renin inhibition in a patient with reninoma. International Journal of Cardiology 187 240-242. (doi:10.1016/j.ijcard.2015.03.280)

Rueda-Camino JA, Losada-Vila B, De Ancos-Aracil CL, RodríguezLajusticia L, Tardío JC, \& Zapatero-Gaviria A 2016 Small cell carcinoma of the prostate presenting with Cushing syndrome: a narrative review of an uncommon condition. Annals of Medicine $\mathbf{4 8}$ 293-299. (doi:10.3109/07853890.2016.1168936)

Said SI \& Faloona GR 1975 Elevated plasma and tissue levels of vasoactive intestinal polypeptide in the watery diarrhea syndrome due to pancreatic, bronchogenic and other tumors. New England Journal of Medicine 293 155-160. (doi:10.1056/ NEJM197507242930401)

Saif MW \& Vethody C 2016 Poorly differentiated neuroendocrine tumor of the esophagus with hypertrophic osteoarthropathy and brain metastasis: a success story. Cureus 8 e646. (doi:10.7759/cureus.646)

Sala E, Ferrante E, Verrua E, Malchiodi E, Mantovani G, Filopanti M, Ferrero S, Pietrabissa A, Vanoli A, La Rosa S, et al. 2013 Growth hormone-releasing hormone-producing pancreatic neuroendocrine tumor in a multiple neoplasia type 1 family with an uncommon phenotype. European Journal of Gastroenterology and Hepatology $\mathbf{2 5}$ 858-862. (doi:10.1097/MEG.0b013e32835f433f)

Selmer C, Madsen JC, Torp-Pedersen C, Gislason GH \& Faber J 2016 Hyponatrema, all-cause mortality, and risk of cancer diagnoses in the primary care setting: a large population study. European Journal of Internal Medicine 36 36-43. (doi:10.1016/j.ejim.2016.07.028)

Shankland KR, Armitage JO \& Hancock BW 2012 Non-Hodgkin lymphoma. Lancet 380 848-857. (doi:10.1016/S0140-6736(12)60605-9)

Shepshelovich D, Leibovitch C, Klein A, Zoldan S, Milo G, Shochat T, Rozen-zvi B, Gafter-Gvili A \& Lahav M 2015 The syndrome of inappropriate antidiuretic hormone secretion: distribution and characterization according to etiologies. European Journal of Internal Medicine 26 819-824. (doi:10.1016/j.ejim.2015.10.020)

Shigetomi S, Ogawa S, Kudo S, Takahashi S \& Fukuchi S 1980 A case of antidiuretic hormone, oxytocin and calcitonin producing oat cell carcinoma of the lung with prominent peritoneal carcinomatosis. Nihon Naika Gakkai Zasshi 69 580-586. (doi:10.2169/naika.69.580)

Shimizu C, Kubo M, Takano K, Takano A, Kijima H, Saji H, Katsuyama I, Sasano H \& Koike T 2001 Interleukin-6 (IL-6) producing phaeochromocytoma: direct IL-6 suppression by non-steroidal antiinflammatory drugs. Clinical Endocrinology 54 405-410. (doi:10.1046/ j.1365-2265.2001.01082.x)

Shimizu H, Monden T, Tomotsune T, Nakatani Y, Domeki N, Matsumura M, Jojima T, Kawagoe Y \& Kasai K 2011 A case of myeloma with hypercalcemia caused by high serum concentrations of both parathyroid hormone-related peptide (PTHrP) and macrophage inflammatory protein-1 $\alpha$ (MIP-1 $\alpha$ ). Internal Medicine 50 2993-2996. (doi:10.2169/internalmedicine.50.6096)

Shionoiri A, Horiuchi T, Onouchi T, Tsutsumi H, Ohta M, Hosoi T, Ito H \& Orimo H 2000 Hypercalcemia induced with the plasma levels of parathyroid hormone-related peptide in multiple myeloma. Internal Medicine 39 810-813. (doi:10.2169/internalmedicine.39.810)

Simsir IY, Kocabas GU, Sahin SB, Erdogan M, Cetinkalp S, Saygili F, Yilmaz C \& Ozgen AG 2012 A case of an ectopic prolactinoma. Gynecological Endocrinology 28 148-149. (doi:10.3109/09513590.2011. 589923)

Somasundaram NP, Garusinghe C \& Grossman AB 2013 Gastrin and ACTH secreting thymic carcinoid tumour causing Zollinger-Ellison and Cushing's syndromes. Hormones 12 305-308. (doi:10.14310/ horm.2002.1415)

Spinazze S \& Schrijvers D 2006 Metabolic emergencies. Critical Reviews in Oncology/Hematology 58 79-89. (doi:10.1016/j. critrevonc.2005.04.004)

Stewart AF 2005 Hypercalcemia associated with cancer. New England Journal of Medicine 352 373-379. (doi:10.1056/NEJMcp042806)

Strewler GJ 2000 The physiology of parathyroid hormone-related protein. New England Journal of Medicine 342 177-187. (doi:10.1056/ NEJM200001203420306)

Sundin A 2012 Imaging of neuroendocrine tumors. Expert Opinion on Medical Diagnostics 6 473-483. (doi:10.1517/17530059.2012.692874)

Szturmowicz M, Wiatr E, Sakowicz A, Slodkowska J, Roszkowski K, Filipecki S \& Rowinska-Zakrzewska ER 1995 The role of human chorionic gonadotropin beta subunit elevation in small-cell lung cancer patients. Journal of Cancer Research and Clinical Oncology 121 309-312. (doi:10.1007/BF01209599)

Takeuchi Y, Takahashi S, Miura D, Katagiri M, Nakashima N, Ohishi H, Shimazaki R \& Tominaga Y 2016 Cinacalcet hydrochloride relieves hypercalcemia in Japanese patients with parathyroid cancer and intractable primary hyperparathyroidism. Journal of Bone and Mineral Metabolism [in press]. (doi:10.1007/s00774-016-0797-0)

Tarin D 2013 Update on clinical and mechanistic aspects of paraneoplastic syndromes. Cancer and Metastasis Reviews 32 707-721. (doi:10.1007/s10555-013-9446-4)

Teale JD \& Wark G 2004 The effectiveness of different treatment options for non-islet cell tumour hypoglycaemia. Clinical Endocrinology $\mathbf{6 0}$ 457-460. (doi:10.1111/j.1365-2265.2004.01989.x)

Teniola SO \& Ogunleye IO 1994 Paraneoplastic syndromes in primary liver cell carcinoma in Nigeria. Tropical and Geographical Medicine $\mathbf{4 6}$ 20-22.

Teves DA 2005 Clinical approach of Cushing syndrome resulting from ACTH-producing metastatic neuroendocrine tumor. Endocrinologist 15 401-404. (doi:10.1097/01.ten.0000188475.05398.09)

Thajudeen B \& Salahudeen AK 2016 Role of tolvaptan in the management of hyponatremia in patients with lung and other cancers: current data and future perspectives. Cancer Management and Research 8 105-114. (doi:10.2147/CMAR.S90169)

Tirone F \& Shooter EM 1989 Early gene regulation by nerve growth factor in PC12 cells: induction of an interferon-related gene. PNAS 86 2088-2092. (doi:10.1073/pnas.86.6.2088)

Tischler AS, Lee YC, Perlman RL, Costopoulos D, Slayton VW \& Bloom SR 1984 Production of 'ectopic' vasoactive intestinal peptide-like and neurotensin-like immunoreactivity in human pheochromocytoma cell cultures. Journal of Neuroscience 4 1398-1404.

Todd JF, Stanley SA, Roufosse CA, Bishop AE, Khoo B, Bloom SR \& Meeran K 2003 A tumour that secretes glucagon-like peptide-1 and somatostatin in a patient with reactive hypoglycaemia and diabetes. Lancet 361 228-230. (doi:10.1016/S0140-6736(03)12256-8)

Todesco S, Terribile V, Borsatti A \& Mantero F 1975 Primary aldosteronism due to a malignant ovarian tumor. Journal of Clinical Endocrinology and Metabolism 41 809-819. (doi:10.1210/jcem-41-5-809) http://erc.endocrinology-journals.org

DOI: $10.1530 /$ ERC-17-0036
(C) 2017 Society for Endocrinology Printed in Great Britain 
Toyoda Y, Nakayama T, Kusunoki Y, Iso H \& Suzuki T 2008 Sensitivity and specificity of lung cancer screening using chest low-dose computed tomography. British Journal of Cancer 98 1602-1607. (doi:10.1038/sj.bjc.6604351)

Trott MJ, Farah G, Stokes VJ, Wang LM \& Grossman AB 2016 A thymic neuroendocrine tumour in a young female: a rare cause of relapsing and remitting Cushing's syndrome. Endocrinology, Diabetes and Metabolism Case Reports 2016 EDM160018. (doi:10.1530/EDM-160018)

Tsolakis AV, Portela-Gomes GM, Stridsberg M, Grimelius L, Sundin A, Eriksson BK, Oberg KE \& Janson ET 2004 Malignant gastric ghrelinoma with hyperghrelinemia. Journal of Clinical Endocrinology and Metabolism 89 3739-3744. (doi:10.1210/jc.2003-032118)

Turkington RW 1971 Ectopic production of prolactin. New England Journal of Medicine 285 1455-1458. (doi:10.1056/NEJM197112232852604)

Tzoulis P, Waung JA, Bagkeris E, Carr H, Khoo B, Cohen M \& Bouloux PM 2016 Real-life experience of tolvaptan use in the treatment of severe hyponatraemia due to syndrome of inappropriate antidiuretic hormone secretion. Clinical Endocrinology 84 620-626. (doi:10.1111/cen.12943)

Van den Eyden GG, Neyret A, Fumey G, Rizk-Rabin M, Vermeulen PB, Bouizar Z, Body JJ \& Dirix LY 2007 PTHrP, calcitonin and calcitriol in a case of severe, protracted and refractory hypercalcemia due to a pancreatic neuroendocrine tumour. Bone 40 1166-1171. (doi:10.1016/j.bone.2006.11.009)

van Essen M, Sundin A, Krenning EP \& Kwekkeboom DJ 2014 Neuroendocrine tumours: the role of imaging for diagnosis and therapy. Nature Reviews Endocrinology 10 102-114. (doi:10.1038/ nrendo.2013.246)

Verbalis JG, Grossman A, Hoybye C \& Runkle I 2014 Review and analysis of differing regulatory indications and expert panel guidelines for the treatment of hyponatraemia. Current Medical Research and Opinion 30 1201-1207. (doi:10.1185/03007995.2014.92 0314)

Von Stempel C, Perks C, Corcoran J \& Grayez J 2013 Cardio-respiratory failure secondary to ectopic Cushing's syndrome as the index presentation of small-cell lung cancer. BMJ Case Reports $\mathbf{2 0 1 3}$ bcr2013009974. (doi:10.1136/bcr-2013-009974)

Weiss DE, Vogel H, Lopes MB, Chang SD \& Katznelson L 2011 Ectopic acromegaly due to a pancreatic neuroendocrine tumor producing growth hormone-releasing hormone. Endocrine Practice 17 79-84. (doi:10.4158/EP10165.CR)

White KE, Jonsson KB, Carn G, Hampson G, Spector TD, Mannstadt M, Lorenz-Depiereux B, Miyauchi A, Yang IM, Ljunggren O, et al. 2001 The autosomal dominant hypophosphatemic rickets (ADHR) gene is a secreted polypeptide overexpressed by tumors that cause phosphate wasting. Journal of Clinical Endocrinology and Metabolism 86 497-500. (doi:10.1210/jcem.86.2.7408)

Wild D, Bomanji JB, Benkert P, Maecke H, Ell PJ, Reubi JC \& Caplin ME 2013 Comparison of $68 \mathrm{Ga}$-DOTANOC and 68Ga-DOTATATE PET/CT within patients with gastroenteropancreatic neuroendocrine tumors. Journal of Nuclear Medicine 54 364-372. (doi:10.2967/ jnumed.112.111724)

Wilson N \& Ngsee J 1980 Large oxytocin and antidiuretic hormone from bronchogenic carcinoma in man. Hormone and Metabolic Research 12 708. (doi:10.1055/s-2007-999240)

Yaturu S, Harrara E, Nopajaroonsri C, Singal R \& Gill S 2003 Gynecomastia attributable to human chorionic gonadotropinsecreting giant cell carcinoma of lung. Endocrine Practice 9 233-235. (doi:10.4158/EP.9.3.233)

Yazawa T, Imamichi Y, Miyamoto K, Khan MR, Uwada J, Umezawa A \& Taniguchi T 2016 Induction of steroidogenic cells from adult stem cells and pluripotent stem cells. Endocrine Journal 63 943-951. (doi:10.1507/endocrj.EJ16-0373)

Ye L, Li X, Kong X, Wang W, Bi Y, Hu L, Cui B, Li X \& Ninq G 2005 Hypomethylation in the promoter region of POMC gene correlates with ectopic overexpression in thymic carcinoids. Journal of Endocrinology 185 337-343. (doi:10.1677/joe.1.05963)

Zhang HY \& Zhao J 2016 Ectopic Cushing in a small cell lung cancer: a case report and literature review. Thoracic Oncology 8 114-117. (doi:10.1111/1759-7714.12403)

Received in final form 21 March 2017

Accepted 24 March 2017

Accepted Preprint published online 24 March 2017
() 2017 Society for Endocrinology Printed in Great Britain
Published by Bioscientifica Ltd 